\title{
ABSTRAKCJI PRZESTRZEŃ WIELORAKA. KATEGORIA PRZESTRZENNOŚCI W TWÓRCZOŚCI WOJCIECHA FANGORA, JERZEGO GRABOWSKIEGO I RYSZARDA WINIARSKIEGO - STUDIUM PORÓWNAWCZE
}

Przestrzeń - zarówno w sztuce, jak i w filozofii, humanistyce, matematyce, fizyce i innych naukach ścisłych - jest jednym z podstawowych punktów odniesienia w jakiejkolwiek refleksji kulturowej ${ }^{1}$. Pojęcie przestrzeni jest zaś kategorią na tyle trwale zakorzenioną $\mathrm{w}$ dyskursie artystycznym i historyczno-artystycznym, że twórcy od wieków w swych dziełach nieustannie jej rozumienie modyfikują, a podążający za nimi badacze sztuki naukowo ją wyjaśniają². Jeśliby ograniczyć się do historii sztuki zachodniej, to należy zauważyć, że istotnych przewartościowań znobilitowanej w nowożytnym malarstwie renesansowej przestrzeni perspektywicznej dokonano ostatecznie na przełomie XIX i XX stulecia, coraz śmielej uwalniając obraz od koligacji przedmiotowych ${ }^{3}$. Perspektywa linearna, oparta na geometrycznym paradygmacie euklidesowym, okazała się być umownym i wcale niejedynym schematem przestrzennego ujęcia rzeczywistości w obrazie - podobnie jak schematy bazujące na geometriach nieeuklidesowych - w żaden sposób koniecznym, a jedynie możliwym ${ }^{4}$.

1 Z.E. Roskal, Koncepcje przestrzeni w nauce i filozofii przyrody, „Roczniki Filozoficzne" 2008, 1(56), s. 292.

2 Zob. L. Shlain, Art \& Physics. Parallel Visions in Space, Time, and Light, New York 2007.

${ }^{3}$ Zob. M. Kemp, The Science of Art. Optical Themes in Western Art from Brunelleschi to Seurat, New Haven-London 1990; M. Kemp, Seen/Unseen. Art, Science, and Intuition from Leonardo to the Hubble Telescope, Oxford 2012.

${ }^{4}$ E. Panofsky, Perspektywa jako „forma symboliczna”, tłum. G. Jurkowlaniec, Warszawa 2008. 
Wystarczy wspomnieć o przestrzeni kubistycznej ${ }^{5}$, świecie suprematystycznej bezprzedmiotowości ${ }^{6}$ czy surrealistycznej mechanice wyobrażeńn ${ }^{7}$, by przekonać się, że już w pierwszych dekadach XX wieku autorytet euklidesowego paradygmatu przestrzeni malarskiej był wyraźnie nadwątlony ${ }^{8}$. Kolejne dekady przypieczętowały trwałość tej tendencji. Rozszerzenie malarstwa na realizacje kinetyczne, formy efemeryczne $z$ happeningiem i performansem na czele, instalacje artystyczne - by zasygnalizować jedynie kilka przejawów wspomnianej tendencji - świadczą o tym dobitnie. Jerzy Ludwiński pisał nawet o fazie przestrzeni w rozwoju światowej sztuki powojennej, chcąc podkreślić niebagatelne znaczenie tej właśnie kategorii artystycznej w długotrwałym procesie redefinicji terminu „dzieło sztuki”. "Czym dla tradycyjnego malarstwa był blejtram, tym dla sztuki etapu przestrzeni staje się wnętrze galerii albo jakakolwiek przestrzeń otwarta dana artyście" ${ }^{\prime \prime}$. Nawiązując do przytoczonych słów Ludwińskiego, w niniejszym tekście zadaję pytanie o to, gdzie leży subtelna, nieostra granica między tym, co w obrazie (w jego blejtramowych ramach), a tym, co poza obrazem (w dopełniającym go trójwymiarowym otoczeniu), i próbuję na nie odpowiedzieć, odwołując się do odpowiednio zdefiniowanej analitycznej kategorii przestrzenności.

Problem ten omówię na przykładach szczególnego rodzaju, które zwykło się etykietować mianem malarstwa abstrakcyjnego. Nie wdając się w dyskusję z licznymi konceptualizacjami abstrakcji tzw. malarstwa nieprzedmiotowego $^{10}$, abstrahując także od polemiki na temat zasadności dualistycznych rozróżnień na abstrakcję i figurację ${ }^{11}$ czy geometrię i naturę ${ }^{12}$, bynajmniej nie deprecjonując ich znaczenia dla teorii i historii sztuki, dystansuję się od roz-

${ }_{5}^{5}$ M. Porębski, Kubizm. Wprowadzenie do sztuki XX wieku, Warszawa 1986, s. 78-88.

6 J. Milner, Kazimir Malevich and the Art of Geometry, New Haven-London 1996.

7 K. Janicka, Surrealizm, Warszawa 1985, s. 29-39.

${ }^{8}$ L.D. Henderson, The Fourth Dimension and Non-Euclidean Geometry in Modern Art, Cambridge-London 2013.

9 J. Ludwiński, Sztuka w epoce postartystycznej, w: idem, Epoka błękitu, red. J. Hanusek, Kraków 2009, s. 193.

10 Zob. Abstraction, red. M. Lind, London-Cambridge 2013; K. Stiles i P. Howard Selz, Theories and Documents of Contemporary Art. A Sourcebook of Artists' Writings, red. K. Stiles, P. Howard, Berkeley 1996, s. 11-168; Y.-A. Bois, R.E. Krauss, Formless. A User's Guide, New York 1997.

11 Zob. S. O'Sullivan, From Aesthetics to the Abstract Machine. Deleuze, Guattari and Contemporary Art Practice, w: Deleuze and Contemporary Art, red. S. Zepke, S. O'Sullivan, Edinburgh 2010, s. 189-207.

12 Zob. P. Sztabińska, Geometria a natura. Polska sztuka abstrakcyjna w drugiej połowie XX wieku, Warszawa 2010. 
patrywania abstrakcji w opozycji do czegoś innego, np. realności, rzeczywistości, reprezentacji lub innych sfer odniesień negatywnych. Pisząc o abstrakcji w związku z malarstwem i grafiką, mam na myśli tę jego cechę, że obraz malarski implikuje w warstwie fenomenologicznej pewien fakt wizualny, który w myślowym postrzeżeniu widza zyskuje dookreślenie pojęcia ogólnego, nie tracąc więzi z tym właśnie pojęciem ogólnym. Innymi słowy, o obrazie abstrakcyjnym pisać będę wtedy, gdy obraz jest ukonkretnieniem własności ogólnej, fenomenem odsyłającym do jakiejś ogólnej własności. Taką własnością ogólną jest na przykład własność zdefiniowana formalnie w sensie logiki formalnej (syntaktycznie lub semantycznie). Obraz taki jest abstrakcyjny w swojej fenomenalności i referencjonalności (odniesieniu). Tak rozumiane abstrakcje malarskie są szczególnego rodzaju obrazami, jak nazywa je Martin Seel - generalnymi ${ }^{13}$. Definicję tę niejednokrotnie wyeksplikuję w trakcie analiz konkretnych realizacji malarskich ${ }^{14}$.

W niniejszym artykule stawiam sobie za cel zaproponowanie jednego z możliwych sposobów pisania o malarstwie abstrakcyjnym, dążąc do zachowania zgodności między porządkiem przedmiotowym i metaprzedmiotowym opisu. Dlatego też ograniczę się do omówienia jednego tylko aspektu wizualności obrazów abstrakcyjnych - aspektu przestrzenności - analizując dzieła trzech polskich twórców. $Z$ uwagi na specyfikę tych dzieł i reprezentowane przez ich twórców postawy artystyczne, zaprezentowane poniżej analizy osadzam w szczególnej ramie metodologicznej, którą dookreślam w części pierwszej artykułu. W części drugiej definiuję analityczną kategorię przestrzenności, na bazie której przeprowadzam studia nad wybranymi obrazami w trzech kolejnych sekcjach artykułu. W części ostatniej podsumowuję dotychczas ujawnione spostrzeżenia, formułując wnioski i naczelną tezę tekstu.

13 „Można [...] odróżnić obrazy «syngularne» od «generalnych». Fotografia lwa w leksykonie służy unaocznieniu generalnych cech tego biologicznego gatunku, a nie temu, by zaprezentować tego lwa. Obrazy generalne są o wiele mniej "gęste» niż obrazy «syngularne»" (M. Seel, Estetyka obecności fenomenalnej, red. K. Wilkoszewska, tłum. K. Krzemieniowa, Kraków 2008, s. 200).

${ }^{14}$ Warto dodać, że obraz abstrakcyjny został powyżej zdefiniowany z punktu widzenia sytuacji recepcji - gdy widz znajduje się przed obrazem, nie znając obiektów (lub abstrahując od ich znajomości), które posłużyły za percepcyjne źródło dla przedstawienia obrazowego, a nie sytuacji kreacyjnej - gdy twórca (nie wyłączając modyfikującego obraz widza, jeśli mowa o rozszerzonym malarstwie) zna wzorce wizualne, z których wyabstrahowano to, co widoczne na obrazie. Zob. A. Kotula, P. Krakowski, Sztuka abstrakcyjna, Warszawa 1977, s. 8-30. 


\section{UWAGI METODOLOGICZNE}

Przedmiotem badań obranym dla niniejszych rozważań jest twórczość plastyczna trzech artystów, docenionych i uwzględnionych w wielu opracowaniach ogólnych poświęconych historii polskiej sztuki po roku $1945^{15}$. Mowa o Wojciechu Fangorze, Jerzym Grabowskim i Ryszardzie Winiarskim. Tym, co łączy twórczość tych artystów, jest nie tylko widoczna na pierwszy rzut oka przynależność ich licznych dzieł do tzw. nurtu abstrakcji geometrycznej, ale również nie mniej istotny fakt konceptualnego związku dzieł i postawy twórczej wspomnianych artystów z ideami zaczerpniętymi z obszaru nauk ścisłych. Fakt ten skłania do przyjrzenia się pracom tych twórców w perspektywie porównawczej, mającej na celu ustalenie, w jaki sposób ów związek z naukami ścisłymi manifestuje się w wizualności obrazów.

Fangor w liście do Bożeny Kowalskiej z roku 1994 pisał:

Moja geometria nie jest Euklidesowa, a raczej Riemannowska i ma więcej wspólnego $z$ trygonometrią sferyczną czy topologią niż z Euklidesem, więcej z czasoprzestrzenią niż mechaniką Newtona, więcej z doznaniem niż rozumowaniem. W oparciu o odkrycie, jakiego dokonałem w 1957 roku - pozytywnej, skierowanej ku widzowi iluzji przestrzeni, zastosowałem ten fenomen do organizacji przestrzeni rzeczywistej ${ }^{16}$.

Grabowski deklarował:

Fascynuje mnie astronomia, fizyka z fizyką o barwie energii etc., psychologia i wiele dziedzin nauk ścisłych, przyrodniczych, technicznych, szczególnie cybernetyka. [...] Matematyka jest najdoskonalszym materiałem „warsztatowym” do mojej pracy twórczej, bo zawiera w sobie konkret i abstrakcję jednocześnie, daje nieograniczoną możliwość relacji o zjawiskach "językiem” obiektywnym, tedy chroni mnie od mojego "ego" chociażby tym, że jest od niego niezależna, poza nim; że otwiera przestrzenie większe niźli ziemskie. Jak filozofia zawiera w sobie obiektywizm i mistycyzm ${ }^{17}$.

Winiarski krótko po zdobyciu głównej nagrody na Sympozjum w Puławach z roku 1966 napisał: „Moją ambicją są próby wizualnego notowania

15 Zob. A. Kępińska, Nowa sztuka. Sztuka polska w latach 1945-1978, Warszawa 1981; J. Bogucki, Sztuka Polski Ludowej, Warszawa 1983; A. Wojciechowski, Młode malarstwo polskie 1944-1974, Wrocław 1983; B. Kowalska, Polska awangarda malarska 1945-1980. Szanse i mity, Warszawa 1988; A. Rottenberg, Sztuka w Polsce 1945-2005, Warszawa 2005.

16 B. Kowalska, Fangor. Malarz przestrzeni, Warszawa 2001, s. 87.

17 B. Kowalska, W poszukiwaniu ładu. Artyści o sztuce, Elbląg-Katowice 2001, s. 68. 
zdarzeń i wizualnej prezentacji ich rozkładów statystycznych. Frapuje mnie wielość możliwości, jakie stwarza takie traktowanie obrazu” ${ }^{18}$, a w rozmowie ze Zbigniewem Taranienką w roku 1990 przyznawał:

Przyszedłem do sztuki z określonego miejsca, mając za sobą myślenie politechniczne, po zainteresowaniach automatyką czy informatyką. Zastanawiałem się, co mógłbym zrobić w sztuce, co by było ważne i dla niej, i dla mnie jako moje dokonania, wiedziałem bowiem, że w obrębie techniki czy technologii istniało wiele spraw, które mogłyby do niej trafić. Myślałem, aby w obręb zdarzeń artystycznych wprowadzić świat odkryć technicznych: teorii gier czy teorii informacji ${ }^{19}$.

Wszyscy ci trzej artyści wielokrotnie przy różnych okazjach wypowiadali się na temat niezaprzeczalnego wpływu, jaki na ich twórczość miały różnorakiej proweniencji teorie i problemy rozpatrywane w naukach ścisłych. Przytoczone wypowiedzi nie tylko stanowią cenne źródło informacji dla badacza, usiłującego opisać relację między sztuką a nauką w twórczości tych artystów. Zaświadczają one także o bardzo istotnym z punktu widzenia historii sztuki fakcie: sztuka odwołująca się w swojej wizualności do nauki nie jest jedynie ilustracją tej drugiej. Na bazie koncepcyjnej nauk ścisłych, prace artystyczne swoją wizualnością wnoszą istotny wkład do kultury, zyskują nową i unikatową jakość, poszerzając granice wizualnej świadomości.

Inspirując się refleksją metodologiczną Ewy Domańskiej ${ }^{20}$ i tym samym wystrzegając się instrumentalnego wykorzystywania istniejących teorii do analizy tak unikatowego zjawiska w sztuce, jakim jest twórczość czerpiąca w swej materii wizualnej z wiedzy ukształtowanej w naukach ścisłych, opowiadam się za potrzebą stworzenia teorii małego zasięgu, respektującej naturę opisanego powyżej przedmiotu badań. Taką teorią o „ograniczonym polu rażenia", niemającą jakichkolwiek ambicji do obejmowania swym zasięgiem wszystkich możliwych do wyszczególnienia zjawisk historyczno-artystycznych, jest jedynie ogólnie zarysowany poniżej projekt umiarkowanego scjentyzmu metodologicznego.

U podstaw umiarkowanego scjentyzmu metodologicznego leży uwiarygodnione historycznym rozwojem nauki założenie, iż nauki matematyczne, a także nauki ugruntowane na języku matematyki i matematycznych formalizacjach, na przestrzeni dziejów wytworzyły aparaturę pojęciową i analitycz-

18 R. Winiarski, Moje próby i poszukiwania, „Polska” 1966, 11(147), s. 42-43.

19 Z. Taranienko, Dialogi o sztuce, Warszawa 2004, s. 182.

${ }^{20}$ E. Domańska, Jakiej metodologii potrzebuje współczesna humanistyka?, „Teksty Drugie" 2010, 1/2, s. 45-55; eadem, Historia egzystencjalna. Krytyczne studium narratywizmu i humanistyki zaangażowanej, Warszawa 2012. 
ną, pozwalającą ściśle i efektywnie, tzn. dość wiernie i użytecznie, opisywać oraz wyjaśniać możliwe do zaobserwowania i zakomunikowania zjawiska, jak również własności rzeczy. Ów opis i wyjaśnienie są do pewnego stopnia uniwersalne, co oznacza, że aparatura matematyczna jest stosowalna do różnych klas obiektów, niezależnie od jednostkowej charakterystyki tych obiektów. Prawdy matematyczne nie są jednak absolutne, czego przekonująco dowiodła dwudziestowieczna filozofia nauki, przypieczętowana postmodernistycznym $\mathrm{w}$ swym duchu konstruktywizmem matematycznym ${ }^{21}$. Dlatego też prezentowane poniżej stanowisko nazwałem umiarkowanym. Nie sądzę bowiem, by jakikolwiek sens miało tłumaczenie pewnych zjawisk literalnie - a zatem tylko tak, jak przyzwala na to teoria matematyczna. Przedmiot badań nauk humanistycznych, a w szczególności historii sztuki, często wymyka się ścisłości terminologii matematycznej i fakt ten należy uszanować ${ }^{22}$. Dlatego matematyka, współtowarzysząca wyjaśnianiu dzieła sztuki, musi respektować jego jednostkowość i uwikłanie w różnorodne relacje w polu sztuki. Odrzucam więc jakąkolwiek nadrzędność matematyki w odniesieniu do przedmiotu badań historii sztuki. Prace artystyczne mają bowiem często wobec nauki charakter polemiczny, nie wspominając o ich przemożnym naddatku ikonicznym. Niesłuszne byłoby więc pominięcie tych faktów w imię realizowania założeń absolutyzującej ideologii scjentystycznejej.

W sukurs tak określonemu stanowisku metodologicznemu przychodzi wielokrotnie dyskutowany i trwale ugruntowany w filozofii nauki pogląd o matematyczności przyrody ${ }^{24}$. Przyroda jest w nim rozumiana jako całokształt możliwej do doświadczenia rzeczywistości - zarówno tej fizycznej, jak i wytwarzanej oraz przeżywanej przez człowieka. Zgodnie z tym poglądem świat jest matematyzowalny, tzn. możliwy do opisania symbolicznym języ-

${ }^{21}$ R.L. Wilder, Kulturowa baza matematyki, w: Współczesna filozofia matematyki. Wybór tekstów, red. R. Murawski, Warszawa 2002, s. 275-292.

22 G.-C. Rota, The Pernicious Influence of Mathematics upon Philosophy, „Synthese” 1991, 2(88), s. 165-178.

${ }^{23}$ J. Skarbek, Scjentyzm, w: Z. Musiał, J. Skarbek, B. Wolniewicz, Trzy nurty: racjonalizm - antyracjonalizm - scjentyzm, Warszawa 2006, s. 189-212.

${ }_{24}$ Matematyczność przyrody, red. M. Heller, J. Życiński, A. Michalik, Kraków 1992; E.P. Wigner, Niepojęta skuteczność matematyki w naukach przyrodniczych, w: Współczesna filozofia matematyki..., s. 293-309; S. Wszołek, Matematyka i metafizyka. Krótki komentarz na temat hipotezy matematyczności świata, "Studia Philosophiae Christianae” 2010, 1(46), s. 25-36; M.L. Hohol, Matematyczność ucieleśniona, w: Oblicza racjonalności. Wokół myśli Michała Hellera, red. B. Brożek, Kraków 2011, s. 143-166; M. Heller, S. Krajewski, Czy fizyka i matematyka to nauki humanistyczne?, Kraków 2014; R. Murawski, Dlaczego matematyka pozwala rozumieć i opisywać świat? Refleksja filozoficzna, w: idem, Z historii logiki i filozofii matematyki, Poznań 2019, s. 133-146. 
kiem matematyki. Pogląd ten nie suponuje, że matematyczne jest wszystko, co tylko może przyjść na myśl. Jak bowiem zmatematyzować ludzkie uczucia lub nieskończoną w swych przejawach złożoność zjawisk społecznych? Pogląd o matematyczności przyrody, opierając się na licznych świadectwach historycznego rozwoju nauki ${ }^{25}$, ekstrapoluje obserwacje $z$ przeszłości i projektuje je na przyszłość, znajdując często potwierdzenie w nieustannie dokonywanych odkryciach naukowych. Dzieło sztuki - jako byt uformowany materialnie w swojej wizualności - także jest częścią opisywanego przez matematykę świata, niezależnie od tego, czy przypisze się je do któregoś z członów przestarzałego rozróżnienia na naturę i kulturęe26.

W związku z przytoczoną powyżej charakterystyką umiarkowanego scjentyzmu metodologicznego kluczowym zagadnieniem dla metodycznego wyjaśniania wizualności i procesualności dzieła sztuki jest kwestia (re)matematyzacji sztuki. Dotyczy ona tego, do jakiego stopnia, opracowując naukowo opisany powyżej typ realizacji artystycznych, badacz matematyzuje przedmiot swych dociekań, tzn. ujmuje go w kategorie matematyczne zgodnie $z$ intencją czy stanem wiedzy artysty lub - ogólniej - z kontekstem powstania pracy, a na ile rematematyzuje przedmiot badań, czyli dodaje w procesie jego wyjaśniania kategorie matematyczne spoza wspomnianego kontekstu. Stwierdzenia na temat występowania bądź niewystępowania pewnych idei matematycznych w dziele danego artysty mają moc większego lub mniejszego prawdopodobieństwa. Stwierdzenia te byłyby bardziej wiarygodne na przykład poprzez odwołanie do programu ukończonych przez artystę lub artystkę studiów technicznych, co ujawniłoby (teoretyczny) zakres nabytej przez niego lub nią wiedzy matematycznej, lub powołanie się na dostępną jemu lub jej literaturę fachową i popularnonaukową na dany temat. Argumentem za opowiedzeniem się po stronie rematematyzacji przedmiotu badań w ujęciu scjentystycznym jest fakt, że matematyka jest nauką o własnościach i obiektach abstrakcyjnych (ogólnych), które - choć są szczególnego rodzaju idealizacjami - nie są całkowicie oderwane od rzeczywistości postrzeganej wizualnie, jako że nierzadko na podstawie obserwacji jej przejawów zostały sformułowa-

25 Zob. M. Kline, Mathematics in Western Culture, New York 1953; E. Kofler, $Z$ dziejów matematyki, Warszawa 1962; J.P. King, The Art of Mathematics, New York 1992, s. 113-121. R. Omnès, Converging Realities. Toward a Common Philosophy of Physics and Mathematics, Princeton 2005.

${ }^{26}$ Zob. R. Dolphijn, I. van der Tuin, Nowy materializm. Wywiady i kartografie, tłum. J. Bednarek, J. Maliński, Gdańsk-Poznań-Warszawa 2018, s. 77-109; D. Haraway, Manifest gatunków stowarzyszonych, w: Teorie wywrotowe. Antologia przekładów, red. J. Bednarek, A. Gajewska, tłum. J. Bednarek, Poznań 2012, s. 241-260. 
ne ${ }^{27}$. Pojęcia matematyczne mają w sobie pewien trudny do wytłumaczenia naddatek jakościowy, który porządkuje przejawy rzeczywistości, czyniąc je inteligibilnymi ${ }^{28}$.

Zasadniczym celem scjentystycznych badań nad sztuką jest wyróżnienie operatywnych kategorii analitycznych, za pomocą których można by dokonywać metodycznych studiów. Mowa o kategoriach porządkujących i wyjaśniających przedmiot badań (wyprowadzonych z wizualności dzieł i zjawisk historyczno-artystycznych), a zatem kategoriach, przez pryzmat których można by opowiedzieć jedną z wielu, przedmiotowo zogniskowanych, „małych” historii sztuki. Jedną spośród tak rozumianych kategorii analitycznych jest zdefiniowana poniżej kategoria przestrzenności.

\section{PRZESTRZENNOŚĆ}

Punktem wyjścia do analizy wizualnej obrazów malarskich i graficznych jest postrzeżenie pewnego faktu wizualnego, w którym sztuczny podział na treść i formę nie znajduje uzasadnienia. Tego typu fakty będę nazywał aksjomatami wizualnymi. Materialnymi substratami faktu wizualnego są możliwe do wyszczególnienia elementy obrazu - jednostki lub znaki, takie jak punkt, linia, zagłębienie, wypukłość, kondensacja barwy, organiczny kształt i inne, także te wymykające się zwięzłej słownej artykulacji. Elementy usytuowane są względem siebie w różnego rodzaju relacjach, zarówno tych wizualnych, jak i tych (w sensie matematycznym) formalnych. Polem, w którym zachodzą te relacje, jest (tak właśnie zdefiniowana) przestrzeń. Relacje zaś zachodzące między elementami przestrzeni tworzą jej geometrię. Geometria jest więc zbiorem „zasad” rządzących elementami danej przestrzeni.

Przestrzeń jest zatem wyznaczana przez swoje elementy i zachodzące między nimi relacje, opisywane przez geometrię tej przestrzeni. Pełna definicja przestrzeni brzmi więc następująco: przestrzeń jest to niezinterpretowany układ wyróżnionych elementów, uporządkowanych geometrycznie. Co oznacza, że układ ten jest niezinterpretowany? Mianowicie to, iż jego opis może być wzbogacony o historyczno-artystyczny kontekst. Własność bycia przestrzenią nazywam przestrzennością.

Nietrudno dostrzec paralelę między powyżej podaną konstrukcją pojęcia przestrzeni i jego uogólnionej własności a sformułowaną przez Davida Hilber-

${ }_{27}$ M. Steiner, The Applicability of Mathematics as a Philosophical Problem, Cambridge-London 1998.

${ }^{28}$ K. Wójtowicz, Spór o istnienie w matematyce, Warszawa 2003. 
ta w roku 1899, przełomową w historii matematyki, aksjomatyzacją geometrii klasycznej29.

Od starożytności geometrię, na co wskazuje etymologia tego terminu (gr. $\gamma \varepsilon \omega$ - 'ziemia', $\mu \varepsilon \tau$ ¿í $\alpha$ - 'mierzenie'), pojmowano jako zbiór zasad motywowanych zastosowaniami praktycznymi. Pełnoprawne narodziny geometrii jako nauki o obiektach abstrakcyjnych - co warto zaznaczyć: nietracących całkowicie związku z percypowaną rzeczywistością - datuje się na przełom IV i III wieku p.n.e., kiedy to Euklides w swoich Elementach spisał całość znanej do jego czasów wiedzy geometrycznej. W kolejnych stuleciach geometria euklidesowa stała się nauką, której twierdzenia miały wartość absolutnej prawdziwości, by w poglądach Immanuela Kanta na naturę przestrzeni zyskać miano koniecznych ${ }^{30}$. Autorytet umocowanej tradycją geometrii klasycznej stopniowo tracił znaczenie w XIX wieku wraz z nastaniem geometrii nieeuklidesowych, a potem unifikującej je geometrii Riemanna ${ }^{31}$. Dzieło Hilberta dało początek rozumieniu geometrii jako nauki całkowicie abstrakcyinej, zrywającej z rzeczywistością empiryczną, stającej się tym samym matematyką czystą. Jej aksjomaty przestały być prawdami oczywistymi czy koniecznymi ${ }^{32}$. Systemy geometrii zyskały status niezinterpretowanych systemów aksjomatycznych, które można interpretować na rozmaite sposoby. Słynne stały się słowa Hilberta, który stwierdził, że "[w] miejsce punktów, prostych i płaszczyzn można zawsze mówić o stołach, krzesłach i kuflach" ${ }^{\prime 33}$. Jak sądzę, idea Hilberta jest o tyle interesująca dla scjentystycznej konceptualizacji obrazu abstrakcyinego, że pozwala mówić o jednej własności przestrzenności, przysługującej każdemu obrazowi, podczas gdy przestrzeni poszczególnych obrazów jest wiele.

Postępowanie metodyczne historyka sztuki, który chciałby zastosować scjentystyczną kategorię przestrzenności do analizy przestrzeni w obrazach abstrakcyjnych, przebiega więc według schematu: wyznaczyć zbiór elementów obrazu (aksjomaty wizualne) $\rightarrow$ rozpoznać zachodzące między nimi relacje (ustalić geometrię przestrzeni) $\rightarrow$ za pomocą pojęć abstrakcyjnych badać własności tych relacji $\rightarrow$ wzbogacić analizę o historyczno-artystyczny kontekst.

29 D. Hilbert, Grundlagen der Geometrie, Leipzig 1903.

${ }^{30}$ M. Heller, Przestrzenie Wszechświata. Od geometrii do kosmologii, Kraków 2017, s. 77-79.

${ }^{31}$ R. Torretti, Philosophy of Geometry from Riemann to Poincaré, Dordrecht 1978, s. $82-107$.

32 R. Murawski, Filozofia matematyki. Zarys dziejów, Poznań 2013, s. 168.

${ }_{33}$ M.-M. Toepell, Über die Entstehung von David Hilberts „Grundlagen der Geometrie”, Göttingen 1986, s. 42. 
Interpretacja określonej scjentystycznie przestrzeni nie jest ograniczona do interpretacji formalnej (w sensie analizy formalnej, klasycznego postępowania badawczego w historii sztuki ${ }^{34}$. Ma ona szerszy zasięg, także kontekstowy. Ewokowana w dziele sztuki przestrzeń może być kojarzona z idiomem wolnościowym, jak dzieje się to w przypadku twórczości Fangora ${ }^{35}$, lub z idiomem ścisłości naukowej - jak u Winiarskiego ${ }^{36}$. Żaden punkt, żadna linia, żadna powierzchnia nie jest niewinna, czyli całkowicie asemantyczna, o czym teoretyczno-artystycznie przekonywał Kandinsky ${ }^{37}$, a co naukowo uzasadniał Arnheim $^{38}$. Postulowana modernistyczna czystość i neutralność dzieła sztuki jest nieczysta i zaangażowana w samym swoim sformułowaniu ${ }^{39}$. Ujęcie scjentystyczne akceptuje „nieczystość” dzieła sztuki, lokując się w polu analizy formalno-kontekstowej dzieła sztuki.

Podsumuję krótko rozważania z tej części wywodu. Sednem opisanego powyżej podejścia scjentystycznego, nakierowanego na analizę zdefiniowanej powyżej przestrzenności w obrazie, jest wyjaśnienie „mechaniki” wizualnej dzieła sztuki łącznie $z$ interpretacją jej systemu. Badanie przestrzeni (obrazu i w obrazie) to sprawdzanie, jak zachowują się w nim pewne (inspirowane matematyką) struktury abstrakcyjne. Celem takiego badania jest próba wyodrębnienia w dziełach poszczególnych artystów pewnych klas przestrzeni, które łączy jakaś idiomatyczna własność, której warianty są reprezentowane przez jednostkowe dzieła.

\section{PRZESTRZEŃ KOSMOGONICZNA: WOJCIECH FANGOR}

Charakteryzowane poniżej obrazy Wojciecha Fangora - są to E 22 i SM 5, powstałe kolejno w latach 1965 i 1974 - realizują sformułowaną przez artystę koncepcję „pozytywnej przestrzeni iluzyjnej”.

${ }^{34}$ Zob. L. Wiesing, Widzialność obrazu. Historia i perspektywy estetyki formalnej, tłum. K. Krzemień-Ojak, Warszawa 2008.

35 S. Szydłowski, Przestrzeń znaczy wolność. O twórczości Wojciecha Fangora, w: Wojciech Fangor. 3 wymiary, Kielce 2005, s. 21-22.

36 Perspektywa sztuki matematycznej, red. W. Skrodzki, „Współczesność. Czasopismo Literackie" 1967, 14(241), s. 8-9.

37 W. Kandinsky, O duchowości w sztuce, tłum. S. Fijałkowski, Łódź 1996; W. Kandinsky, Punkt i linia a płaszczyzna. Przyczynek do analizy elementów malarskich, tłum. S. Fijałkowski, Łódź 2019.

${ }^{38}$ Zob. R. Arnheim, Sztuka i percepcja wzrokowa. Psychologia twórczego oka, tłum. J. Mach, Łódź 2013.

39 J. Margolis, Po dwóch stronach debaty wokół modernizmu/postmodernizmu, w: idem, Czym, w gruncie rzeczy, jest dzieło sztuki? Wykłady z filozofii sztuki, red. K. Wilkoszewska, tłum. W. Chojna, Kraków 2004, s. 12-26. 
Dla wywołania „Pozytywnej Przestrzeni Iluzyjnej” powinny być spełnione pewne warunki: 1. Unikanie ujawniania powierzchni obrazu, a więc faktury, położeń pędzla, grubości farby itp. 2. Prostota i minimalizm kształtów przenikających z brzegów bądź z narożników prostokąta obrazu. 3. Prostota kształtu płótna, a więc raczej kwadrat niż wydłużony prostokąt, który ma dwie kontrastujące osie pion i poziom. Kształty o kątach ostrych ograniczają możliwości efektów bezkrawędziowych. Stąd kształty obłe, jak fale, elipsy, koła ${ }^{40}$.

Cechą rozpoznawalną obrazów namalowanych w konwencji „pozytywnej przestrzeni iluzyjnej" jest doznawane w percepcji wrażenie wychodzenia wizerunku przed płaszczyznę obrazu. Przestrzeń ta jest jakby odwrotnością renesansowej perspektywy zbieżnej. „Gdy tamta daje złudzenie zanurzania się w głąb obrazu - ta stwarza iluzję wydobywania się i ulatywania przestrzeni z obrazu w kierunku oczu widza” ${ }^{\prime 4}$. Zagadnienie „pozytywnej przestrzeni iluzyjnej" zajmowało miejsce kluczowe w filozofii twórczej Fangora, dlatego badacze i znawcy sztuki wspominali o nim niemal przy każdej okazji, gdy pochylali się nad spuścizną tego artysty. Niemniej jednak liczne opisy „pozytywnej przestrzeni iluzyjnej", choć niezwykle cenne, jeśli uwzględnić zawartą w nich drobiazgowość obserwacji przeprowadzonej z punktu widzenia psychologii percepcji, nie skupiają się na zdumiewającej „mechanice” samej przestrzeni, która - jak podkreślają badacze i sam artysta - jest w swej istocie abstrakcyjna ${ }^{42}$. Ponadto komentatorzy twórczości Fangora niezwykle często podkreślają znaczenie astronomii, fizyki i matematyki w ukształtowaniu koncepcji „pozytywnej przestrzeni iluzyjnej”"43. Brakuje jednak - jak zauważył już w roku 2005 Stefan Szydłowski44 - szczegółowych analiz poszczególnych obrazów, mierzących się z zadaniem wyjaśnienia znaczenia inspiracji płynących z nauk ścisłych.

40 Wojciech Fangor. 25.09.2009-15.11.2009. Atlas Sztuki, red. S. Szydłowski, Warszawa 2009 , s. 42.

${ }^{41}$ B. Kowalska, O kilku różnych przestrzeniach Wojciecha Fangora, w: Wojciech Fangor. 3 wymiary..., s. 4-5.

42 Eadem, s. 6; Rozmowa z Wojciechem Fangorem. Kwiecień-Maj 2003, w: Wojciech Fangor (Centrum Sztuki Współczesnej Zamek Ujazdowski Warszawa, 16 września 26 października 2003), Warszawa 2003, s. 9-10, 70; S. Szydłowski, Wojciech Fangor. 3 wymiary - retrospektywa, Orońsko 2015, s. 90-91.

${ }^{43}$ Kowalska, Fangor. Malarz przestrzeni..., s. 67; eadem, O kilku różnych przestrzeniach..., s. 6; M. Knorowski, Analisis situs, czyli topologia według Fangora, w: Wojciech Fangor. 3 wymiary..., s. 25; S. Szydłowski, Wojciech Fangor. Przestrzeń jako gra, Kraków 2012, s. 50.

${ }^{44}$ Szydłowski, Przestrzeń znaczy wolność..., s. 19. 
Punktem wyjścia do analizy scjentystycznej przestrzeni w obrazach Fangora jest sformułowanie aksjomatów wizualnych. Dostarcza ich literatura badawcza. Wystarczy chociażby przytoczyć opis Bożeny Kowalskiej, dotyczący klasy przestrzeni reprezentowanej przez obraz E 22 (il. 1):

Wszystkie formy otoczone były aureolami sfumato, przechodząc od swojej właściwej barwy do, najczęściej neutralnego, koloru tła. Fangor zdaje się w owych czterech czy pięciu latach po 1957 roku poszukiwać najtrafniejszej formy dla zastosowania swojego odkrycia. Cieszy go złudny ruch, wywoływany trudnościami akomodacyjnymi oczu, na próżno usiłujących wydobyć skonkretyzowany kształt z jego zamglonych zarysów. Cieszy go przywidzenie pulsowania obrzeży form, zbliżania się ich i oddalania, niemożność koncentracji wzorku. Zjawisko urojonej pulsacji skłania do użycia kształtów obłych i form falistych, by sprawdzić, jak iluzja oczu nakładać się będzie na zbliżone do złudnych, rzeczywiste formy malarskie ${ }^{45}$.

W konkretnym przypadku E 22 neutralnym kolorem tła jest biel, która od naroży płótna przechodzi w kolejno jasne i ciemne odcienie najpierw błękitu, a następnie ciemne i jasne odcienie zieleni, by w partii centralnej obrazu powrócić do swojej wyjściowej neutralności. Niemożliwe jest dostrzeżenie w obrazie klarownie wyodrębnionych jednostek, takich jak np. wyraźnie zarysowane i rozgraniczone pola o jednakowej wartości kolorystycznej. Stąd jako elementarne jednostki można przyjąć w tym przypadku punkty. Punkty rozumiane jako jednostki niematerialne, pozbawione wymiarów i nieskończenie małe, lecz z przysługującą im jakościową własnością, np. koloru. W tym sensie punkty mogą tworzyć ciągi, a także wchodzić w skład większych struktur wizualnych, takich jak okręgi czy koła, by w tym celu zaświadczać o przysługujących przestrzeni własnościach abstrakcyjnych, wyznaczających relacje między punktami ${ }^{46}$. A zatem przestrzeń w E 22 jest zbiorem punktów. Geometrią tej przestrzeni są relacje zachodzące w zbiorze tak wyróżnionych elementów.

Widoczna na E 22 struktura kolista jest plastyczną realizacją niewizualnej w swej istocie, występującej w wielu działach współczesnej matematyki struktury, którą nazywa się kulą otwartą ${ }^{47}$. Jest to szczególny przypadek zbioru otwartego ${ }^{48}$, który cechuje się tym, że - obrazowo rzecz ujmując - pozbawiony

${ }^{45}$ Kowalska, Fangor. Malarz przestrzeni..., s. 105-106.

46 Taka interpretacja punktów w przestrzeni koresponduje z ideą leżącą u podstaw zainicjowanego przez Gottfrieda Wilhelma Leibniza (i niezależnie od niego Isaaca Newtona) rachunku różniczkowego i ściśle z nim powiązaną monadologią. Zarówno monadologię, jak i rachunek różniczkowy sformułował Leibniz jako próbę wyjaśnienia szeroko pojętego zjawiska ciągłości. Zob. D. Garber, Leibniz. Body, Substance, Monad, Oxford 2009.

${ }^{47}$ K. Kuratowski, Wstęp do teorii mnogości i topologii, Warszawa 1977, s. 105.

48 Ibidem, s. 113. 


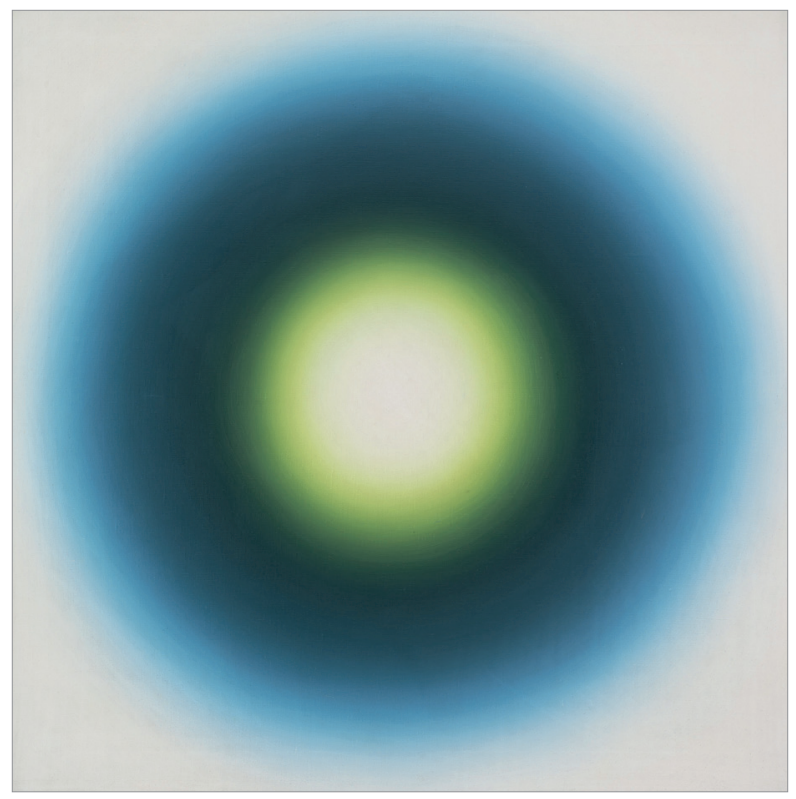

1. Wojciech Fangor, E 22, olej na płótnie, 1965, Muzeum Sztuki w Łodzi

jest on swojego brzegu ${ }^{49}$. Trudno wyobrazić sobie taką strukturę. Być może pomocna okaże się próba wyobrażenia sobie dowolnego przedmiotu znanego z codzienności, np. krzesła lub książki, pozbawionych swoich powierzchni. Trochę trywializując własność otwartości zbioru, można powiedzieć, że kula otwarta przypomina pozbawioną skórki pomarańczę, która po obraniu nie miałaby wyraźnie zarysowanej granicy, organizującej obecny w niej miąższ. Kula otwarta byłaby czymś w rodzaju obranej ze skórki pomarańczy, rozpatrywanej łącznie z pustym miejscem po obranej skórce. Na obrazie Fangora nie ma jednej kuli otwartej, lecz jest ich niekończąca się seria. Środkiem każdej takiej kuli jest centralny punkt obrazu, znajdujący się na przecięciu przekątnych kwadratowej ramy obrazu. Długości promieni kul przyjmują wartość liczbową od zera do długości bliskiej połowie boku kwadratowego płótna obrazu. Ciąg zagnieżdżonych w sobie kul jest zstępujący (lub patrząc negatywowo - wstępujący ${ }^{50}$ i faktem tym można tłumaczyć pulsującą dynamikę jego widocznej na obrazie struktury. Artysta ukazał w swym dziele unikalną wła-

49 J. Mioduszewski, Wykłady z topologii. Topologia przestrzeni euklidesowych, Katowice 1994, s. 26.

50 G.M. Fichtenholz, Rachunek różniczkowy i całkowy, t. 1, tłum. T. Huskowski, R. Bittner, B. Gleichgewicht, Warszawa 1999, s. 70. 
sność ujawnionej w nim przestrzeni: widoczne jest wnętrze każdej z kul przy iluzorycznym zarysie ich granic. Podział na wnętrze i zewnętrze jest w niej przełamany.

Kolejną własność przestrzeni w E 22 można uwypuklić, posługując się pojęciem ciągu uogólnionego ${ }^{51}$. Jeśliby nadać każdemu $z$ widocznych na obrazie pierścieni (których grubość jest punktowa, tzn. dąży do zera, będąc w istocie wielkością nieskończenie małą) wielkość odpowiadającą, podążając za sugestią artysty ${ }^{52}$, długości fali świetlnej przysługującej danemu kolorowi w widmie promieniowania elektromagnetycznego, to uzyskałoby się w ten sposób nieskończony ciąg liczbowy, którego monotonicznośćc ${ }^{53}$ charakteryzowałaby modulację kolorystyczną i metryczną (odległościową) przestrzeni.

Warto zauważyć, że Fangor w E 22 zastosował odcienie, które odgrywają szczególne znaczenie w optyce ${ }^{54}$. Wbrew klasycznej optyce i potocznemu odczuciu, a w zgodzie z ustaleniami optyki kwantowej, większy ładunek energetyczny (temperaturę barwową) od kolorów ciepłych mają kolory zimne, takie jak błękit i ciemna zieleń. Co więcej, temperatura barwowa błękitu jest wyższa niż zieleni ${ }^{55}$. W świetle tych ustaleń, energia w E 22 rozprzestrzenia się koliście, ku granicom ram obrazu, korespondując $z$ optycznym złudzeniem wychodzenia przestrzeni przed lico powierzchni płótna. Jak myślę, istotny jest też tutaj fakt, że w obrazie dokonuje się wielowalorowe przejście od bieli do bieli - od koloru neutralnego do koloru neutralnego. Fangor był zafascynowany topologią, a w szczególności topologicznymi własnościami powierzchni jednostronnych, czego artystycznym przejawem było wytrwałe przepracowywanie wielowariantowego motywu wstęgi Möbiusa ${ }^{56}$. Biel w centrum pola obrazowego E 22 i na jego obrzeżach, czyli w tych fragmentach obrazu, które zyskały w historii malarstwa szczególne znaczenie jako wstępne punkty

${ }^{51}$ R. Duda, Wprowadzenie do topologii, cz. 1: Topologia ogólna, Warszawa 1986, s. $120-121$.

52 W. Fangor, ENTER/ESCAPE - Jak malarstwo kształtuje nowe przestrzenie? (Wypowiedzi uczestników wystawy), „Sztuka i Dokumentacja” 2010, 2, s. 75.

53 Fichtenholz, Rachunek różniczkowy..., s. 58.

${ }^{54}$ H. Breuer, Atlas fizyki, Warszawa 2000, s. 172-173.

55 Zagadnienie temperatury barwnej odgrywało istotną rolę w twórczości Kajetana Sosnowskiego, o czym pośrednio wspomina Bożena Kowalska (zob. B. Kowalska, Kajetan Sosnowski. Malarz niewidzialnych światów, Warszawa 1998, s. 29). Pojęcie temperatury barwowej, co ciekawe w kontekście naukowych inspiracji w twórczości Fangora, stosuje się w astronomii, gdy chce się dookreślić promieniowanie gwiazdy w przypadku, gdy całkowite emitowane przez nią widmo jest nieznane. Zob. E. Rybka, Astronomia ogólna, Warszawa 1975 , s. 378 .

56 Zob. Kowalska, Fangor. Malarz przestrzeni..., s. 87; Szydłowski, Wojciech Fangor..., s. 130 . 
orientacyine dla oglądu namalowanego wizerunku ${ }^{57}$, jest jednocześnie początkiem i końcem pewnej struktury przestrzennej. W tym sensie przestrzeń w E 22 nie ma początku ani końca, a co za tym idzie - jej wizualna "głębia" balansuje między skierowaniem w stronę widza a uchodzeniem przed jego spojrzeniem. Innymi słowy, jednoznaczność dwuwymiarowej płaszczyzny obrazu zanurzonej w fizycznej, trójwymiarowej przestrzeni zostaje względem tej drugiej upłynniona - abstrakcyjna przestrzeń w E 22 fluktuuje między drugim a trzecim wymiarem, być może tym samym korespondując $z$ Fangorowską interpretacją czasoprzestrzeni ${ }^{58}$.

Przestrzeń analizowanego obrazu jest ciągła ${ }^{59}$, co według jednej z równoważnych w matematyce wykładni i w odniesieniu do E 22 oznacza, że dla dowolnie małej zmiany odległości (mierzonej np. odcinkami) między dwoma bliskimi sobie punktami przestrzeni, zmiana walorów kolorystycznych właściwych tym punktom jest też mała. Przejścia między okrężnie rozprowadzonymi strefami kolorów są więc niemal niezauważalne, brakuje im punktów nieciągłości ${ }^{60}$. Jeżeli można mówić o logice oglądu ciągłości w obrazie Fangora, to jest to raczej nieklasyczna logika rozmyta ${ }^{61}$, a nie logika klasyczna $z$ jej prawem wyłączonego środka ${ }^{62}$. Rozumiem przez to fakt, iż możliwe do wyodrębnienia w obrazie obszary (mniejsze lub większe) są zbiorami rozmytymi $^{63}$, co oznacza, że należące do nich elementy, paradoksalnie (ale zgodnie $z$ teorią i jej empirycznymi zastosowaniami) należą do nich (do owych zbiorów rozmytych) jedynie z pewnym prawdopodobieństwem. Innymi słowy, dla pewnych fragmentów płótna określić niedeiktycznie (tzn. pojęciowo, intelektualnie, nie wskazując jednoznacznie na któryś z punktów obrazu poprzez podanie jego współrzędnych) przynależność do nich postrzeganego odcienia koloru można jedynie w sposób przybliżony, a nie jednoznaczny (jak byłoby w logice klasycznej, operującej tylko dwoma wartościami: tak-nie/prawda-fałsz $\left.{ }^{64}\right)$. Przestrzeń $E 22$ cechuje więc abstrakcyjnie uogólniona rozmytość, czyli niejednoznaczność klasyfikacyjna jej elementów.

Jeżeli obraz przedstawia zstępujący ciąg promieniejących ze środka otwartych kul, zasadne byłoby pytanie o geometrię jej wyobrażeniowych po-

${ }_{57}$ Zob. Arnheim, Sztuka i percepcja wzrokowa...

58 Kowalska, Fangor. Malarz przestrzeni..., s. 72.

59 Fichtenholz, Rachunek różniczkowy..., s. 122-123.

60 Ibidem, s. 129-130.

${ }^{61}$ J.J. Buckley, E. Eslami, An Introduction to Fuzzy Logic and Fuzzy Sets, Heidelberg 2013, s. 17.

62 T. Batóg, Podstawy logiki, Poznań 2003, s. 55.

63 A. Piegat, Modelowanie i sterowanie rozmyte, Warszawa 1999, s. 17.

${ }^{64}$ K. Świrydowicz, Podstawy logiki modalnej, Poznań 2014, s. 13-15. 
wierzchni. Nietrudno zauważyć, że powierzchnie te mają strukturę sfery dwuwymiarowej rozmaitości (Riemannowskiej), czyli takiej struktury, która w bardzo małym przybliżeniu swojego dość dużego obszaru wykazuje własności geometrii euklidesowej, natomiast w oddaleniu przypomina geometrię nieeuklidesową o dodatniej krzywiźnie (geometrię eliptyczną), charakteryzowaną przez szereg własności ${ }^{65}$.

Opisana własność rozmaitości, dotycząca różnic geometrycznych w skali globalnej i lokalnej, zyskuje zdumiewającą nośność semantyczną na poziomie interpretacji układu elementów przestrzeni. Wiadomo, że genezy „pulsujących obrazów" Fangora należałoby doszukiwać się w jego rozwijanej od dzieciństwa pasji do astronomii ${ }^{66}$. Zaobserwowane we wczesnych latach zjawisko aberracji chromatycznej (jak zauważył artysta na marginesie swoich rozważań na temat soczewek wypukłych, „powierzchnia wypukła odpycha i rozprasza przestrzeń" $\left.\right|^{67}$ miało niemały wpływ na kształtowanie się świadomości wizualnej artysty ${ }^{68}$. Na poziomie odniesień przedmiotowych obrazy z cyklu, do którego należy E 22, przypominają pulsujące światłem gwiazdy, rozsiane po niezliczonych zakątkach Wszechświata. Sferyczne gwiazdy, z daleka widoczne jako rozmaitość Riemannowska, w swoim ogromnym przybliżeniu (podobnie jak dzieje się to w przypadku naszej planety) stają się płaskie - płaskie jak płaszczyzna materialnie obecnego przed widzem obrazu. Dzieła Fangora w wykreowanych przez niego kosmicznych spektaklach znoszą zatem możliwe jedynie do wyobrażenia astronomiczne odległości w scjentystycznym oglądzie. Zasugerowana w obrazie geometria Riemannowska sprawia, że fizyczna przestrzeń widza jest ukonkretnieniem obecnej w E 22 przestrzeni abstrakcyjnej.

Wyobrażeniowe doświadczanie pokonywania astronomicznych odległości zdaje się stawiać wyzwanie prędkości światła - jedynej absolutnej wielkości fizycznej, jaka pozostała fizykom po rewolucji wywołanej teorią względności. Obrazy Fangora wyzwalają tym samym ogromne pokłady viriliowsko rozumianej energii kinematycznej ${ }^{69}$. „Pulsary” Fangora, w tym także E 22,

${ }^{65}$ B.A. Rosenfeld, History of Non-Euclidean Geometry. Evolution of the Concept of a Geometric Space, New York 1988, s. 289-297.

66 S. Szydłowski, Wprowadzenie, w: Wojciech Fangor. Heweliusz, red. I. Ziętkiewicz, Sopot 2015, s. 7-8.

${ }^{67}$ Kowalska, Fangor. Malarz przestrzeni..., s. 82.

${ }^{68}$ Knorowski, Analisis situs, czyli topologia..., s. 26.

69 „Skoro fizycy wyróżniają zwykle dwa aspekty energii: energię potencjalną jako moc i energię kinematyczną, jako tę, która wyzwala ruch, to być może należałoby dorzucić dziś do tego jej trzeci rodzaj: energię kinematyczną, opartą na oddziaływaniu ruchu wraz z jego większą lub mniejszą prędkością w obrębie postrzeżeń wizualnych, optycznych i opto-elek- 
w swojej centralnej części mają własność zbioru, który w teorii układów dynamicznych nazywa się atraktorem ${ }^{70}$. Przyciągając zstępująco uporządkowane kule otwarte, punkt centralny obrazu kumuluje w sobie rozprzestrzeniającą się energię układu przestrzennego, sugerując tym samym źródło tego układu, który w interpretacji naukowej nasuwa skojarzenia $z$ Wielkim Wybuchem lub powstawaniem gwiazdy.

Przestrzeń obrazu SM 5 (il. 2), choć w pewnych aspektach podobna do przestrzeni „pulsarów”, wykazuje wiele cech odmiennych. Podobnie jak w E 22, tak i tutaj elementami przestrzeni są niematerialne, scharakteryzowane jakościowo punkty, wyznaczające przestrzeń zachodzącymi między sobą rela-

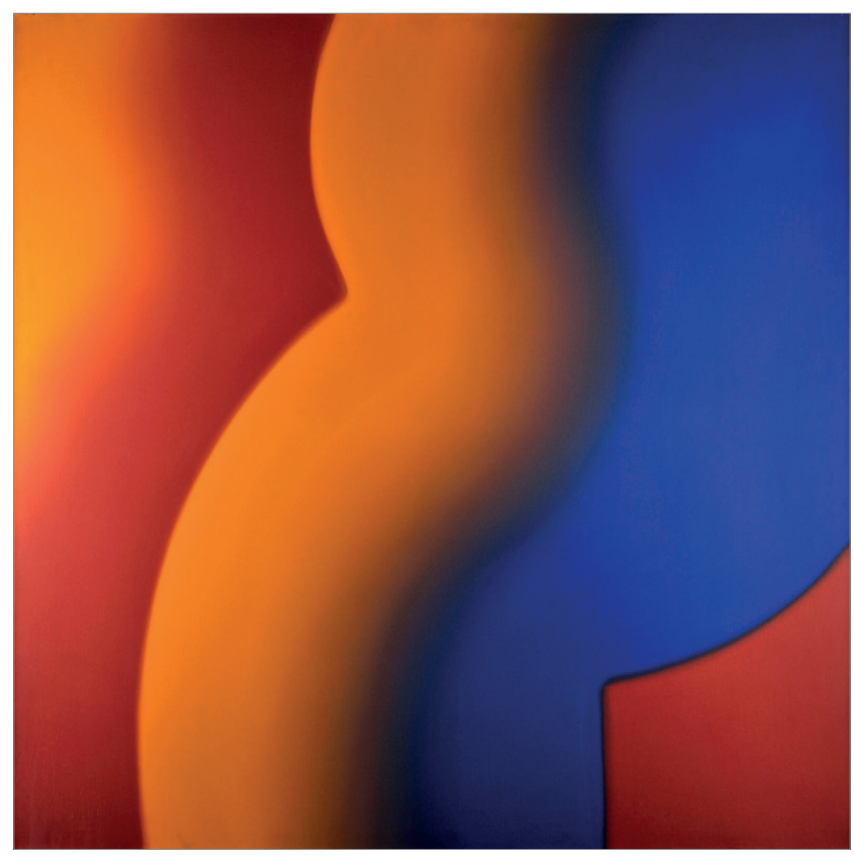

2. Wojciech Fangor, SM 5, olej na płótnie, 1974, Fundacja Rodziny Staraków

tronicznych" (P. Virilio, Maszyna widzenia, w: Widzieć, myśleć, być. Technologie mediów, red. A. Gwóźdź, Kraków 2001, s. 39-62). O ile fizyczne zapędy Virilio są dalece przesadzone, czego dowodzą Sokal i Bricmont (A.D. Sokal, J. Bricmont, Modne bzdury. O nadużywaniu pojęć z zakresu nauk ścisłych przez postmodernistycznych intelektualistów, tłum. A. Lewańska, P. Amsterdamski, Warszawa 2004, s. 164-169|, o tyle w odniesieniu do wyobrażeniowej mechaniki widzenia, jak sądzę, są jak najbardziej godne uwagi.

${ }^{70}$ H.-O. Peitgen, H. Jürgens, D. Saupe, Fraktale. Granice chaosu, cz. 2, tłum. K. Pietruska-Pałuba i K. Winkowska-Nowak, Warszawa 2002, s. 329. 
cjami geometrycznymi. Ciągłość nie jest tym razem własnością globalną przestrzeni, choć nadal dominuje. Można bowiem wyróżnić dwa liniowe obszary nieciągłości - jeden w prawym dolnym narożu płótna, drugi w lewym kompartymencie obrazu. W ramach tych liniowych obszarów występują punkty, w których zarysowują się pola wklęsłości, zaburzające regularność falowego uporządkowania przestrzeni. W tych obszarach przejścia między graniczącymi ze sobą strefami barwnymi nie są płynne, lecz skokowe - ciągi punktów tych stref dążą do granicy ${ }^{71}$, ulokowanej w obszarach nieciągłości. Dzięki temu poszczególne strefy barwne (od lewej: żółtopomarańczowa, karminowa, żółtobrązowa, niebieska, ciemnoczerwona) są zbiorami otwarto-domkniętymi. Logika przynależności barwnej jest tutaj mieszana, niekiedy klasyczna, kiedy indziej rozmyta. Punkty inicjujące pola wklęsłości „przesuwają” swym oddziaływaniem strefy przejść ciągłych i sprawiają, że strefy te są zakrzywione w ten sposób, że mają punkty przegięcia ${ }^{72}$, w których dokonuje się zamiana rozmytego konturu z wklęsłego na wypukły i odwrotnie. Nie jest to już przestrzeń jednorodna, regularna w swojej geometrii jak ta w E 22. O ile tę drugą cechuje neutralizacja napięć kierunkowych, o tyle w SM 5 występuje ich kondensacja.

Obie przestrzenie łączy charakter sugerowanych przez nie nieskończoności. W matematyce wyróżnia się dwa zasadnicze typy nieskończoności: nieskończoność potencjalną i nieskończoność aktualną. Nieskończoność potencjalna to możliwość nieograniczonego przedłużania pewnego procesu bez uzyskania końcowego wyniku ${ }^{73}$. Nieskończoność aktualna to - jak sama nazwa wskazuje - obecnie istniejący obiekt, który jest rezultatem teoretycznie nieograniczonego procesu konstrukcji ${ }^{74}$. W odniesieniu zarówno do $E 22$, jak i do $S M 5$ zasadne jest mówienie o nieskończoności aktualnej, bowiem obecna w nich ciągłość i rozmytość implikuje bowiem nieograniczoną, niewyobrażalnie małą zmienność jakościową, której przejawy w dowolnym postrzeżeniowym przybliżeniu obrazu odbierane są jako zastane, istniejące uprzednio.

Podsumowując zarysowane powyżej analizy dwóch tylko obrazów Fangora, reprezentowane przez nie przestrzenie można nazwać kosmogonicznymi. Są to bowiem przestrzenie kształtowania się i powstawania - stawania się, a nie wyłonionej już jako rezultat określoności. Przestrzeń kosmogoniczna to przestrzeń nowego świata, wyłaniającego się na oczach widza, jest bogata w nieokreśloność i zarazem pełna abstrakcyjnych własności, sugerujących płynną naturę jej formowania się.

${ }^{71}$ Fichtenholz, Rachunek różniczkowy..., s. 35-36.

72 Ibidem, s. 264.

73 R. Murawski, Nieskończoność w matematyce. Zmagania z potrzebnym, acz kłopotliwym poięciem, „Zagadnienia Filozoficzne w Nauce” 2014, 55, s. 8.

${ }^{74}$ R. Murawski, K. Świrydowicz, Wstęp do teorii mnogości, Poznań 2005, s. 118-119. 


\section{PRZESTRZEŃ TRANSCENDENCJI: JERZY GRABOWSKI}

Zupełnie odmiennego typu przestrzeń można dostrzec w pracach Jerzego Grabowskiego. W grafice z roku 1969 (il. 3) elementy przestrzeni są dwojakiego rodzaju. Elementy pierwszego rodzaju to - podobnie jak w obrazach Fangora - nieskończenie małe punkty, mające kolorystyczne własności jakościowe. Z nich składa się gradientowa część grafiki. Drugi rodzaj tworzą pojedyncze, modularne jednostki w kształcie trójkątów, nakładane na siebie w układzie naprzemiennym. Co charakterystyczne dla linorytów Grabowskiego, jednostki te są perforowane, dzięki czemu grafika dyskretnie otwiera się na otaczającą ją przestrzeń fizyczną, wprowadzając subtelnie jej wklęsło-wypukłe modulacje.

W przestrzeni Symetrii ciagu monotonicznego można więc wyróżnić dwie podprzestrzenie: jedną, definiowaną przez przysługującą jej własność ciągłości (w znaczeniu opisanym powyżej), oraz drugą - dyskretną ${ }^{75} \mathrm{w}$ swej naturze. Dyskretność oznacza, znacznie abstrahując od jej teoretycznego bogactwa, wyizolowanie jednostek lub - inaczej rzecz ujmując - możliwość ich jednoznacznego rozdzielenia i łączenia w większe zbiory. Współistnienie tych dwóch przestrzeni w jednym obrazie skłania do dostrzeżenia implikowanych tym faktem relacji porównawczych.

Ciąg monotoniczny, o którym mowa w tytule pracy, znajduje swą wizualną realizację w dwóch podprzestrzeniach obrazu. W przestrzeni ciągłej jest on wyrażony gradientowym przejściem od pasma ciemnej zieleni do neutralnej bieli w lewej części i od pasma bieli do intensywnej czerwieni w prawej części. Warto nadmienić, że neutralność bieli w twórczości Grabowskiego zyskiwała częstokroć konkretną wartość liczbową - zero ${ }^{76}$. Lewy segment barw chłodnych składa się z walorów usytuowanych w dolnej części wiązki świetlnej, uzyskanej po przejściu światła białego przez pryzmat (sugestię odwołania się do pryzmatu wzmacnia fakt zastosowania trójkątnego modułu „wbitego" w gradient). Prawy segment gromadzi zaś barwy ciepłe. W górnej partii przestrzeni dyskretnej można zaobserwować analogiczne własności: moduły lewej części sugerują opadanie, podczas gdy moduły prawej - wznoszenie. Układ modułów w dolnej partii jest jednolity, sprawia wrażenie wyważonego. Zawarta w jego lokalnym przybliżeniu dynamika (wywoływana diagonalami wznoszącymi i opadającymi, generowanymi trójkątnym kształtem) zyskuje neturalizację w globalnym oddaleniu. Obie podprzestrzenie swoimi odmiennymi własnościami korelują ze sobą, stanowiąc realizację sformułowanego

${ }^{75}$ Duda, Wprowadzenie do topologii..., s. 108.

76 S. Dudzik, Jerzy Grabowski. Artysta i uniwersum, Ząbki 2012, s. 29. 


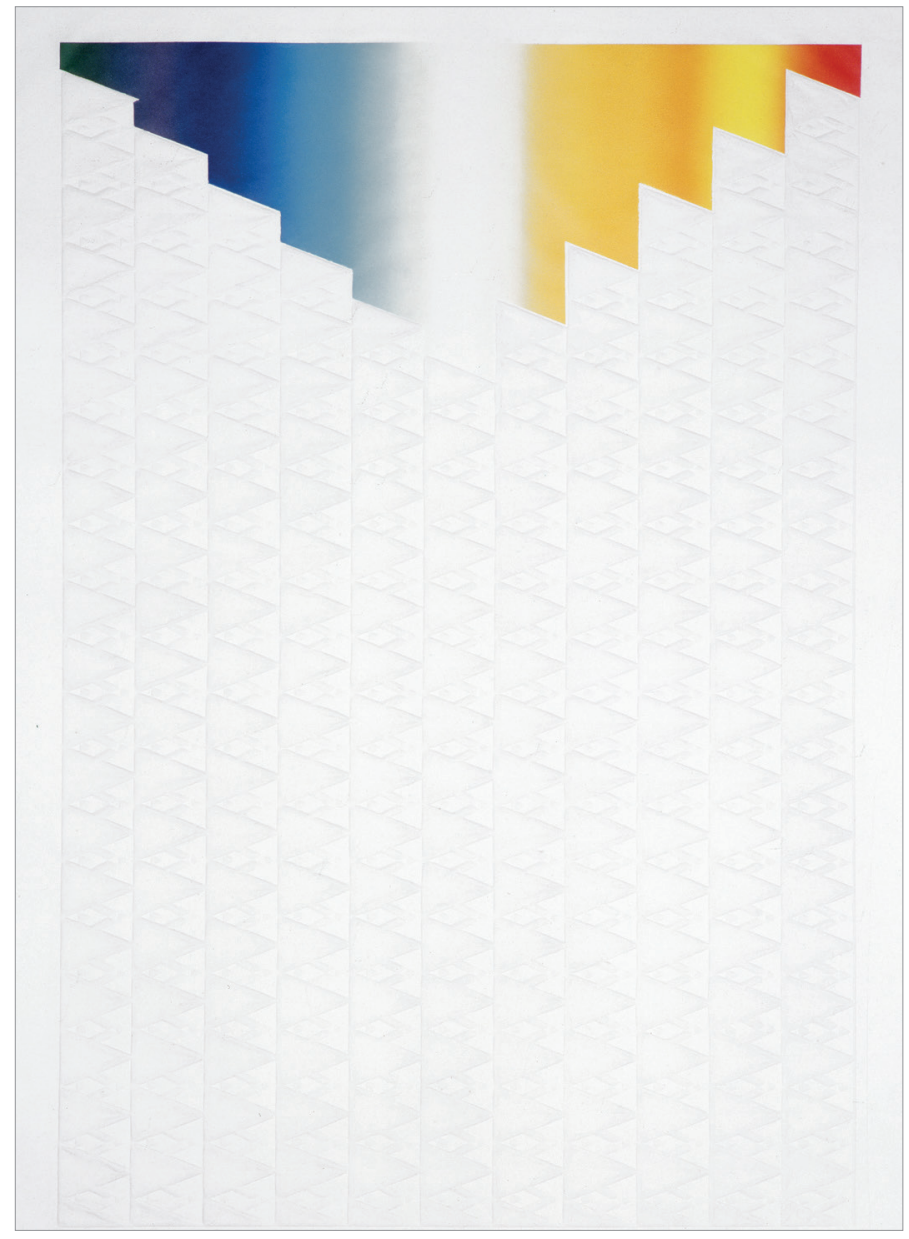

3. Jerzy Grabowski, Symetria ciagu monotonicznego, linoryt barwny prasowany, 1969, kolekcja Zachęty - Narodowej Galerii Sztuki

przez artystę postulatu ukazywania $\mathrm{w}$ pracach zaobserwowanej w naturze jedności przeciwieństw ${ }^{77}$. Obie w jakościowym oglądzie nachodzą na siebie w punkcie leżącym na pionowej osi symetrii pola obrazowego. Przestrzeń obrazu, składająca się z tych dwóch podprzestrzeni, ma więc matematyczną własność dualności ${ }^{78}$.

Matematyka była dla Grabowskiego, jak sam się o niej wyraził w zacytowanej wcześniej wypowiedzi, „najdoskonalszym materiałem «warsztato-

77 B. Kowalska Sztuka struktur matematycznych, w: Jerzy Grabowski (1933-2004). Grafika i rysunek, red. M. Nowakowska, tłum. E. Rodzeń-Leśnikowska, Łódź 2008, s. 4.

${ }^{78}$ Murawski, Świrydowicz, Wstęp do teorii mnogości..., s. 61. 
wym»". Źródeł niesłabnącego zamiłowania artysty do współczesnej nauki należy doszukiwać się m.in. w podjętych przez niego studiach architektonicznych na Politechnice Wrocławskiej ${ }^{79}$. Fakt ten tłumaczyłby posługiwanie się przez artystę w swoich szkicach i publikowanych tekstach fachową terminologią matematyczną, niewolną jednak od subiektywnych interpretacji, wykraczających poza jej ściśle naukowe rozumienie. Sądząc po wypowiedziach Grabowskiego ${ }^{80}$, matematykę pojmował on na sposób platoński, by nie powiedzieć - pitagorejski, tzn. był pewien istnienia rzeczywistości ponadzmysłowej, w której bytują idealne obiekty matematyczne (prawzory wszystkich zmysłowo poznawanych rzeczy), a zasadą nimi rządzącą jest liczba ${ }^{81}$. Występująca w twórczości Grabowskiego szeroko pojęta matematyka ma więc wymiar platoński. Układ przestrzenny obrazów tego artysty silnie wiąże się tym samym z kontekstową interpretacją idealistyczną.

W przypadku Grabowskiego punktem wyjścia do pracy nad kolejnymi obrazami były rozważania natury nie tyle ikonicznej, ile analitycznej. W trakcie ich przeprowadzania artysta posługiwał się ciągami liczbowymi i abstrakcyjnymi własnościami matematycznymi, takimi jak monotoniczność lub porządek wyznaczany przez daną klasę funkcji, np. wielomianów Legendre'a ${ }^{82}$. Przykładowo, opracowując warstwę wizualną jednej z prac z cyklu Operacje $z$ komputerem, artysta dysponował ciągiem losowo wygenerowanych liczb (zestawionych w wierszach i kolumnach), który następnie usiłował uporządkować, wykonując na sąsiadujących ze sobą liczbach operacje arytmetyczne ${ }^{83}$. Następnie Grabowski wprowadzał zasady kodowania liczb kolorami, przypisując np. wartościom parzystym walor zieleni, natomiast nieparzystym - walor czerwieni. Warstwa wizualna tak skomponowanego obrazu jest więc w interpretacji platońskiej jedynie zewnętrzną powłoką „prawdziwej”, wedle słów samego Grabowskiego ${ }^{84}$, rzeczywistości liczb. Dzieło sztuki w tym kontekście jest więc uobecnieniem i nośnikiem prawdy metafizycznej, stanowiąc ontologiczny dowód na matematyczność przyrody. Uczytelnia ono możliwy do zaobserwowania w naturze, jak wyraził się artysta, „uporządkowany, logiczny chaos cyfr" ${ }^{\prime \prime 5}$.

79 Jerzy Grabowski (1933-2004)..., s. 124.

${ }^{80}$ Ibidem, s. 63; Kowalska, W poszukiwaniu ładu..., s. 68.

${ }^{81}$ G. Reale, Historia filozofii starożytnej, t. 2: Platon i Arystoteles, Lublin 2008, s. $124-130$.

82 Dudzik, Jerzy Grabowski..., s. 75.

${ }^{83}$ Ibidem, s. 44.

84 Jerzy Grabowski (1933-2004)..., s. 63.

85 Szkic Progresja cyfr dynamiczna. Studium alternatywy 10-tej, 1976 (Dudzik, Jerzy Grabowski..., il. 46, s. 135). 
Podprzestrzeń dyskretna Symetrii ciagu monotonicznego ma znaną $z$ geometrii fraktalnej własność samopodobieństwa ${ }^{86}$, co w uproszczeniu oznacza, że jej część zawiera w sobie charakterystykę całości. Każdy z trójkątnych modułów podzielony jest bowiem na mniejsze, podobne ${ }^{87}$ do wyjściowego, budując jednocześnie większe, możliwe do dyskretnego wyodrębnienia trójkątne jednostki, także podobne do wyjściowego modułu ${ }^{88}$. Analityczna własność samopodobieństwa ma wartość nie tylko opisową. Jest także koncepcyjnym środkiem, jaki artysta zastosował, by zasugerować platońską naturę obrazu, odsyłającego do porządku obecnego w przyrodzie. Podprzestrzeń w grafice Grabowskiego ma bowiem budowę triangularną, której pitagorejczycy, a także ulegający wpływom ich filozofii Platon, przypisywali szczególne znaczenie metafizyczne jako budulcowi pierwiastków wszechrzeczy ${ }^{89}$. Przykładem takiej figury jest tetraktys, pitagorejski symbol doskonałości ${ }^{90}$. Figury triangularne symbolizują rozrost, progresję i jako takie odsyłają do greckiego sposobu pojmowania liczby. Inaczej niż to jest dzisiaj, po zakończonej sukcesem arytmetyzacji matematyki starożytni Grecy nie interpretowali liczby arytmetycznie, lecz geometrycznie. Odejmując czy mnożąc różne wielkości, wykonywano działania na figurach geometrycznych, np. odcinkach, a nie na symbolicznie zapisywanych liczbach, tak jak czyni się to dzisiaj ${ }^{11}$. Z takiego pojmowania pojęcia liczby wynikły liczne paradoksy, takie jak paradoks niewspółmierności czy paradoksy nieskończoności, które doprowadziły do pierwszego kryzysu podstaw matematyki ${ }^{92}$. Przyjęty przez Grabowskiego na początku jego drogi twórczej i przez dekady konsekwentnie realizowany program wykorzystywania trójkątnego modułu jako podstawowej jednostki komponowanych w obrazach przestrzeni obciążony jest więc silnym ładunkiem kulturowym. Być może wpływ na genezę tej strategii, prócz wykazywanych przez artystę inklinacji filozoficznych, miał fakt stosowania triangulacyjnych technik analitycznych i wizualiza-

${ }^{86}$ H.-O. Peitgen, H. Jürgens, D. Saupe, Granice chaosu. Fraktale, cz. 1, tłum. K. Pietruska-Pałuba, K. Winkowska-Nowak, Warszawa 1997, s. 186.

87 F. Reinhardt, H. Soeder, Atlas matematyki, Warszawa 2006, s. 161.

88 Struktura Symetrii ciagu monotonicznego przypomina więc znany w geometrii fraktalnej trójkąt Sierpińskiego. Zob. Peitgen et al., Granice chaosu..., cz. 1, s. 122.

${ }^{89}$ Diogenes Laertios, Żywoty i poglądy słynnych filozofów, tłum. I. Krońska, K. Leśniak, W. Olszewski, B. Kupis, Warszawa 2004, s. 196.

90 Porfiriusz, Żywot Pitagorasa, w: Żywoty Pitagorasa, red. i tłum. J. Gajda-Krynicka, Wrocław 1993, s. 10.

${ }^{91}$ I. Bondecka-Krzykowska, Przewodnik po historii matematyki, Poznań 2006, s. 41.

92 T. Batóg, Dwa paradygmaty matematyki. Studium z dziejów i filozofii matematyki, Poznań 2000. 
cyjnych we współczesnej matematyce i informatyce93, z którymi Grabowski zapewne miał styczność jako adept wykładanej na politechnice architektury.

Zabieg tłumaczenia logiki pojęciowego porządku ciągu liczbowego na wizualny porządek graficzny, czyli czynnika ilościowego na jakościowy, jeszcze wyraźniej widoczny jest w akwareli Struktura progresji XII. Interwencja szara (il. 4), wchodzącej w skład cyklu Progresje ${ }^{94}$. Podobnie jak w Symetrii ciagu monotonicznego, tak i tutaj w ramach przestrzeni jednego obrazu współistnieją ze sobą dwie podprzestrzenie - dyskretna i ciągła. Jednostki obu są zróżnicowane kolorystycznie. Grabowski wprowadzanie do wielu kompozycji niesymetrycznych przestrzeni gradientowych, nazywanych przez niego polami, wyjaśniał chęcią uzyskania przeciwwagi dla rozdrobnionego układu wyraziście zgrupowanych trójkątów ${ }^{95}$. W Strukturze progresji XII element gradientowy swoim równoległobocznym kształtem naprowadza widzenie patrzącego na dostrzeżenie zarysowujących się diagonalnie przejść kolorystycznych, zróżnicowanych w dynamice swoich zmian walorowych. Ukierunkowanie patrzenia naprowadza widza na myśl o istnieniu lokalnych, widocznych na ograniczonym polu obrazowym nieporządków, które w globalnym oglądzie obrazu (możliwego do uzyskania dzięki kontynuacji transkodowania kolejnych wartości ciągu liczbowego na odpowiadające im kolory) zyskałyby czytelniejszy sens w strukturze większej całości ${ }^{96}$. To, co w symbolicznym zapisie liczbowym wymagałoby czasochłonnej analizy, w odbiorze wizualnym zyskuje niemal natychmiastową artykulację. Każdy z punktów kwadratowej siatki jest nośnikiem informacji o liczbowej bliskości lub oddaleniu połączonych jednym wierzchołkiem trójkątnych modułów. Wspomniane punkty są zatem jakościowymi jednostkami miary ilościowych w swej istocie odległości.

Wpływ na wizualny i koncepcyjny kształt twórczości Grabowskiego, co zauważył Sebastian Dudzik ${ }^{97}$, ma inspiracja ludową sztuką tkacką, wyraźnie dostrzegalna zwłaszcza we wczesnych pracach artysty, takich jak Gradacja na trójkąt z roku 1969 i powstałych rok później Infiltracjach i Działaniu przekątnych. Zaakcentowanie tej właśnie inspiracji jest o tyle cenne, że wiąże się

${ }^{93}$ K. Jänich, Topologia, tłum. D. Czarnocka-Cieciura, G. Cieciura, Warszawa 1991, s. 93-94. O triangulacji wspomina też Mieczysław Porębski, omawiając przestrzeń kubistyczną (idem, Kubizm..., s. 83-85).

${ }^{94}$ Pierwsze notatki i szkice do tego cyklu powstały w połowie roku 1975. Prace nad cyklem kontynuował Grabowski przez blisko dziesięć kolejnych lat (Dudzik, Jerzy Grabowski..., s. 83).

95 Ibidem s. 93.

96 Grabowski wielokrotnie w swoich szkicach sugerował tego rodzaju ekstrapolację obrazu, domalowując także moduły, które wykraczają poza ramę przewidzianego do finalnej realizacji obrazu.

${ }^{97}$ Dudzik, Jerzy Grabowski..., s. 29. 


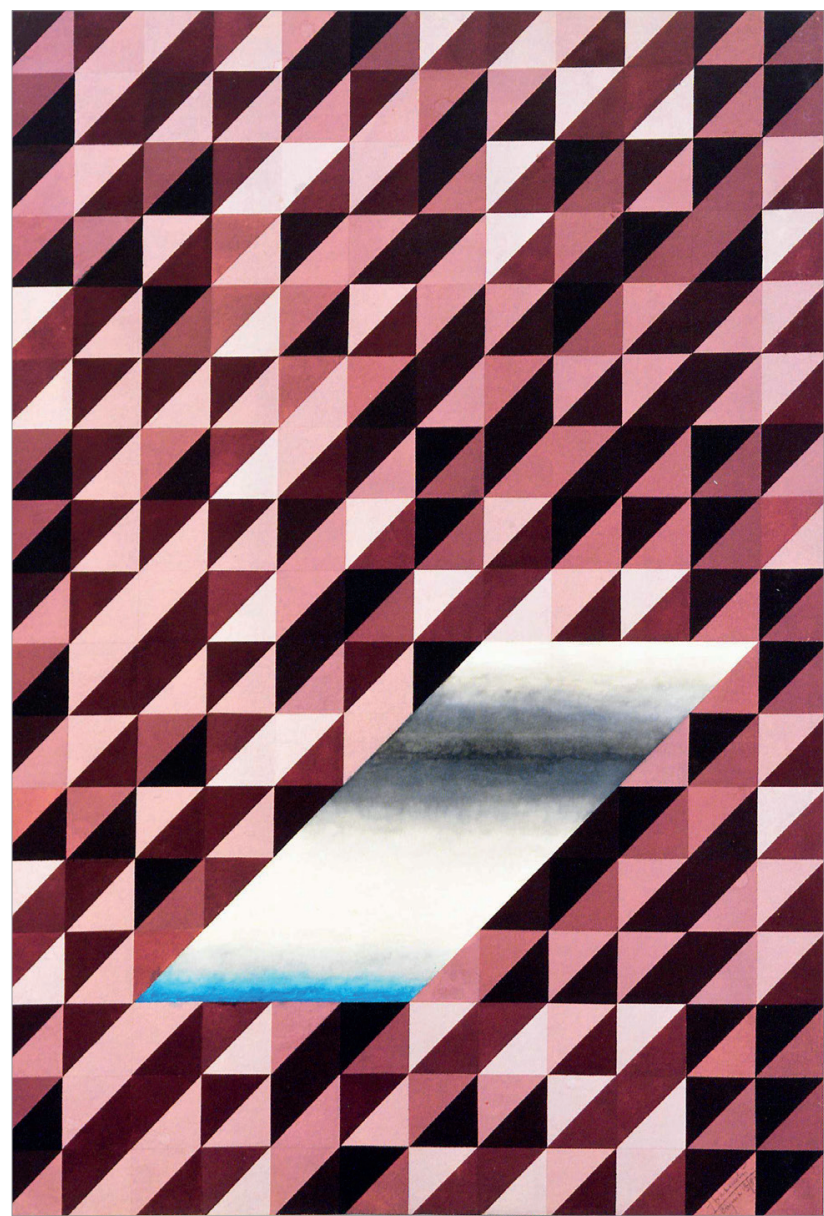

4. Jerzy Grabowski, Struktura progresii XII. Interwencja szara, akwarela na papierze, 1978, kolekcja prywatna

w historii matematyki z początkami automatycznych urządzeń liczących, których rozwój doprowadził do wynalezienia współczesnych komputerów. Charles Babbage - twórca projektu bezpośredniego pierwowzoru komputera (maszyny analitycznej) - przystępując do prac koncepcyjnych nad swoim wynalazkiem w roku 1833, wykorzystał pomysł zastosowania kart perforowanych (powierzchnia grafik Grabowskiego też jest perforowana), dzięki którym Joseph Jacquard w roku 1805 skonstruował mechanizm przesmykowy, będący częścią mechanicznego krosna tkackiego ${ }^{98}$. Produkcja tkanin jest

98 I. Bondecka-Krzykowska, Historia obliczeń. Od rachunku na palcach do maszyny analitycznej, Poznań 2012, s. 222-223. 
ściśle powiązana z koniecznością przestrzegania matematycznych procedur algorytmicznych ${ }^{99}$. Matematyczny wymiar prac Grabowskiego nie dotyczy więc jedynie ich analitycznej logiki oraz wizualności, lecz także sposobu ich „wytwarzania”.

Przestrzeń Struktury progresji XII, a także w mniejszym stopniu przestrzeń Symetrii ciągu monotonicznego, uwidacznia napięcie między dwoma rodzajami nieskończoności. Podprzestrzeń ciągła sugeruje nieskończoność aktualną, podczas gdy podprzestrzeń dyskretna stwarza pole do zaistnienia oglądowo doświadczanej nieskończoności potencjalnej, wywołanej ogromną ilością możliwych do wyszczególnienia kolorystycznych kombinacji trójkątnych jednostek. Przestrzenie tych dwóch obrazów, reprezentatywnych dla pewnej grupy prac artysty, są więc $\mathrm{w}$ swoich fragmentach zarówno potencjalnie, jak i aktualnie nieskończone.

Zróżnicowana w swych wariantach przestrzeń analizowanych tutaj obrazów Grabowskiego jest więc przestrzeniq transcendencji - nie tylko ze względu na jej interpretację metafizyczną, lecz przede wszystkim dzięki łączeniu dwóch różnych jakościowo porządków przestrzennych (ciągłość i dyskretność, aktualność i potencjalność), które wykraczają poza swoje ograniczenia, zyskując dopełnienie w podprzestrzeni lub nadprzestrzeni dualnej względem siebie.

\section{PRZESTRZEŃ PROBABILISTYCZNA: RYSZARD WINIARSKI}

Przestrzenie w obrazach i reliefach Ryszarda Winiarskiego - czy może w obszarach, jak artysta radził nazywać swoje dzieła - poza nielicznymi wyjątkami są w zasadzie przestrzeniami całkowicie dyskretnymi. Ich elementami są bowiem najczęściej białe lub czarne, wyizolowane jednostki kwadratowe, często uzupełnione w poszczególnych realizacjach elementami reliefowymi lub iluzorycznymi.

W pracy Od 0 do 100\% czerni (il. 5), składającej się z dwudziestu sześciu kwadratowych paneli, połączonych ze sobą w układzie liniowym, dostrzegalnym na pierwszy rzut oka aksjomatem wizualnym jest narastanie liczby czarnych jednostek kwadratowych w każdym $z$ kolejnych paneli w taki sposób, że pierwszy panel składa się wyłącznie z białych jednostek, ostatni zaś - wyłącznie z czarnych jednostek.

99 C. Brezine, Algorithms and Automation. The Production of Mathematics and Textiles, w: The Oxford Handbook of the History of Mathematics, red. E. Robson, J.A. Stedall, Oxford-New York 2009, s. 468-492. 


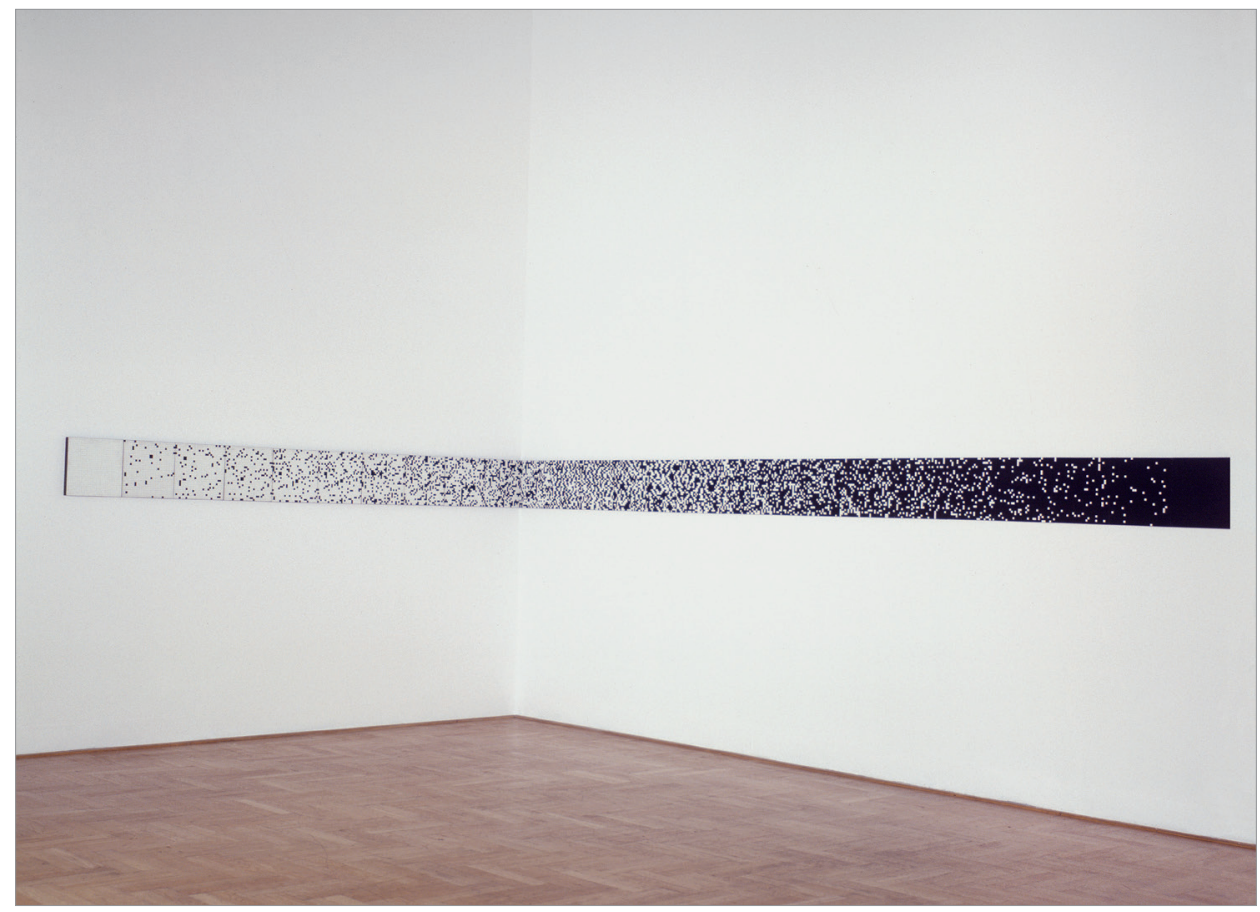

5. Ryszard Winiarski, Od 0 do 100\% czerni, akryl na sklejce, 1975, kolekcja Zachęty - Narodowej Galerii Sztuki

Tworząc swoje prace, artysta wykorzystywał mechanizm losowy (np. rzucając sześcienną kostką do gry), uzyskując wyniki, które interpretował w zależności od przyjętego dla danej realizacji programu ${ }^{100}$. Mówiąc nieco precyzyjniej, Winiarski stosował w procesie malowania obszarów zmienne losowe o rozkładzie dyskretnym ${ }^{101}$. Abstrahując od matematycznej złożoności zagadnienia, tego typu zmienne losowe (odróżniane od zmiennych losowych ciągłych) cechują się własnością nieciągłości, tzn. przejścia między różnymi wartościami zmiennej losowej dyskretnej są skokowe i wyraźnie dostrzegalne. Tak też jest we wspomnianej pracy Winiarskiego. Artysta w licznych autokomentarzach zarysowywał różne konteksty interpretacyjne swych dzieł, chcąc rozjaśnić znaczenie osobliwej morfologii wizualnej obszarów. Przywoływał konteksty $\mathrm{m}$.in. dokonanej w XX wieku demistyfikacji procesu tworze-

100 Kowalska, W poszukiwaniu ładu..., s. 167.

101 J. Jakubowski, R. Sztencel, Rachunek prawdopodobieństwa dla (prawie) każdego, Warszawa 2002, s. 78. 
nia dzieła sztuki ${ }^{102}$, matematycznego obiektywizmu ${ }^{103}$, a także (szczególnie często od początku lat 80.) metafizycznego idealizmu matematycznego ${ }^{104}$.

Przestrzeń w Od 0 do 100\% czerni, sama w sobie dyskretna, sygnalizuje dostrzegalną w swej wizualności iluzję ciągłego przejścia. Dwadzieścia sześć paneli układa się bowiem w ciąg, którego granicą jest pole całkowicie czarne lub pole całkowicie białe w zależności od punktu przyjętego za początek tego ciągu. Czerń i biel są według Winiarskiego wartościami jednoznacznymi w swej opozycji, dlatego można im przypisać interpretacje wszelkich możliwych skrajnych dualizmów, takich jak dobro/zło, prawda/fałsz czy coś/ nicość $^{105}$. Biel i czerń były też utożsamiane przez artystę $z$ zerem i jedynką, dzięki czemu każdy z paneli mógłby być zapisany jako ciąg binarny, który w zapisie dwójkowym ${ }^{106}$ oznaczałby jedną konkretną liczbę. Przestrzeń, której abstrakcyjna narracja, opowiadana językiem binarnego ciągu, rozwija się w sposób liniowy, ma więc charakter segmentowy. Innymi słowy, całkowita przestrzeń dzieła składa się z dwudziestu sześciu podprzestrzeni dyskretnych, których własnościami rządzą nieznacznie zmodyfikowane zmienne losowe. Układ tych podprzestrzeni w strukturze całości wywołuje w oglądzie wrażenie płynności i pozornej ciągłości. Ilościowa jednoznaczność tych podprzestrzeni, a także przestrzeni jako całości, niejako roztapia się w jakościowej wartości ikonicznej obrazu.

Odczucie przestrzennej ciągłości, której iluzoryczność dodatkowo wydobyto widocznym na reprodukcji zaaranżowaniem pracy w narożu pomieszczenia, wzmocniono linearnością układu paneli, dzięki czemu każdy z wierszy kwadratowych jednostek w całościowo rozpatrywanej przestrzeni układa się w ciąg powtarzający logikę całości przestrzeni. Dzięki temu można powiedzieć, że przestrzeń w realizacji Winiarskiego, podobnie jak w obrazach Grabowskiego, ma własność samopodobieństwa. Napięcie między pozorną ciągłością a rzeczywistą dyskretnością przestrzeni uwydatnia podział całości na dwadzieścia sześć kwadratowych segmentów, pociągający za sobą fakt rozbicia liniowości ciągu białych i czarnych jednostek w obrębie każdego z pojedynczych paneli, wyłączywszy pierwszy i ostatni spośród nich. Co ciekawe, analizowana praca opisywaną tu własnością przestrzeni zapowiada szereg mniejszych w swej skali realizacji, o ukierunkowaniu wertykalnym lub horyzontalnym, tworzonych

102 Taranienko, Dialogi o sztuce..., s. 184-185.

103 Wywiad z Ryszardem Winiarskim, rozm. D. Skaryszewska, „Projekt” 1985, 5(164), s. 23.

104 Taranienko, Dialogi o sztuce..., s. 186.

105 J. Olek, Porządek przypadku, czyli o Winiarskim, w: Ryszard Winiarski. Prace z lat 1973-1974, red. J. Grabski, Kraków 2002, s. 17.

106 R. Kawa, J. Lembas, Wstęp do informatyki, Warszawa 2017, s. 42-44. 
przez artystę od początku lat 70. ${ }^{107}$ Akcentowana w ten sposób liniowość procesów przypadkowych koresponduje z opracowanymi przez Winiarskiego w roku 1977 programami przebiegów logicznych, wyznaczającymi pole jego prób twórczych na ponad dwadzieścia kolejnych lat ${ }^{108}$.

Subtelnie zasugerowane w grafikach Grabowskiego otwarcie płaszczyznowego obrazu na przestrzeń trójwymiarową zyskuje formę radykalną w reliefowych obszarach Winiarskiego, takich jak Obszar 144 z roku 1973 (il. 6). Penetrujące przestrzeń rzeczywistą prostopadłościenne słupki mają tutaj niejednoznaczny status ontologiczny. Wywodzą się one z płaszczyznowego, schematycznego i abstrakcyjnego zapisu zmiennej losowej i zyskują w obiektowym medium obrazowym rzeczywistą, skierowaną w stronę widza, niemal dotykalną formę. Ta zadziwiająca $z$ ontologicznego punktu widzenia własność przestrzeni Obszaru 144 - którą można by nazwać materialną konkretyzowalnością tego, co abstrakcyjne - jest według badaczy nowych mediów własnością wytwarzanych w wirtualnych rzeczywistościach „abstrakcyjnych systemów”, „mających na celu uwidocznienie tego, co poza zasięgiem ludzkiego oka, lub tego, co jako takie nie może zostać zobaczone, na przykład różne statystyczne, losowe lub dynamiczne procesy"109. We wspomnianych elementach reliefowych obszarów Winiarskiego przestrzeń staje się więc dualna, łącząc w sobie dwa różne porządki wymiarowe - płaszczyznowy i fizyczny.

Przestrzeń w obu omawianych tu pracach, podobnie jak w większości obrazów i obiektów Winiarskiego, ma własność nieskończoności potencjalnej. Fakt ten wynika bezpośrednio $z$ dyskretności tej przestrzeni. Zbiór dyskretny jest bowiem co najwyżej przeliczalny, tzn. albo skończony, albo nieskończony w sensie nieskończoności potencjalnej-nigdy aktualnej. Przykładowo Obszar 144 swoim programem, ale i obrazowym wynikiem tego programu, odsyła do zbioru możliwości, jakie mogłyby zaistnieć alternatywnie, gdyby stosowane przez artystę zmienne losowe przyjęły w trakcie wykonywania obrazu wartości inne niż te wylosowane w konkretnym miejscu i czasie malowania obrazu. Obszar 144 składa się bowiem z dziesięciu tysięcy jednostek kwadratowych, które mogłyby przyjąć „wartość” białą lub czarną. Z elementarnego wzoru kombinatorycznego na liczbę wszystkich wariacji z powtórzeniami ${ }^{110} \mathrm{dla}$ od-

107 B. Schröder, Konkrete Kunst. Mathematisches Kalkül und programmiertes Chaos, Berlin 2008, s. 142.

108 Ryszard Winiarski. Event-Information-Image, red. A. Muszyńska, M. Marczak-Cerońska, Warszawa 2017, s. 104-139.

109 T. Elsaesser, M. Hagener, Teoria filmu. Wprowadzenie przez zmysły, tłum. K. Wojnowski, Kraków 2015, s. 232.

110 Z. Palka, A. Ruciński, Wykłady z kombinatoryki. Przeliczanie, Warszawa 2007, s. 36 . 


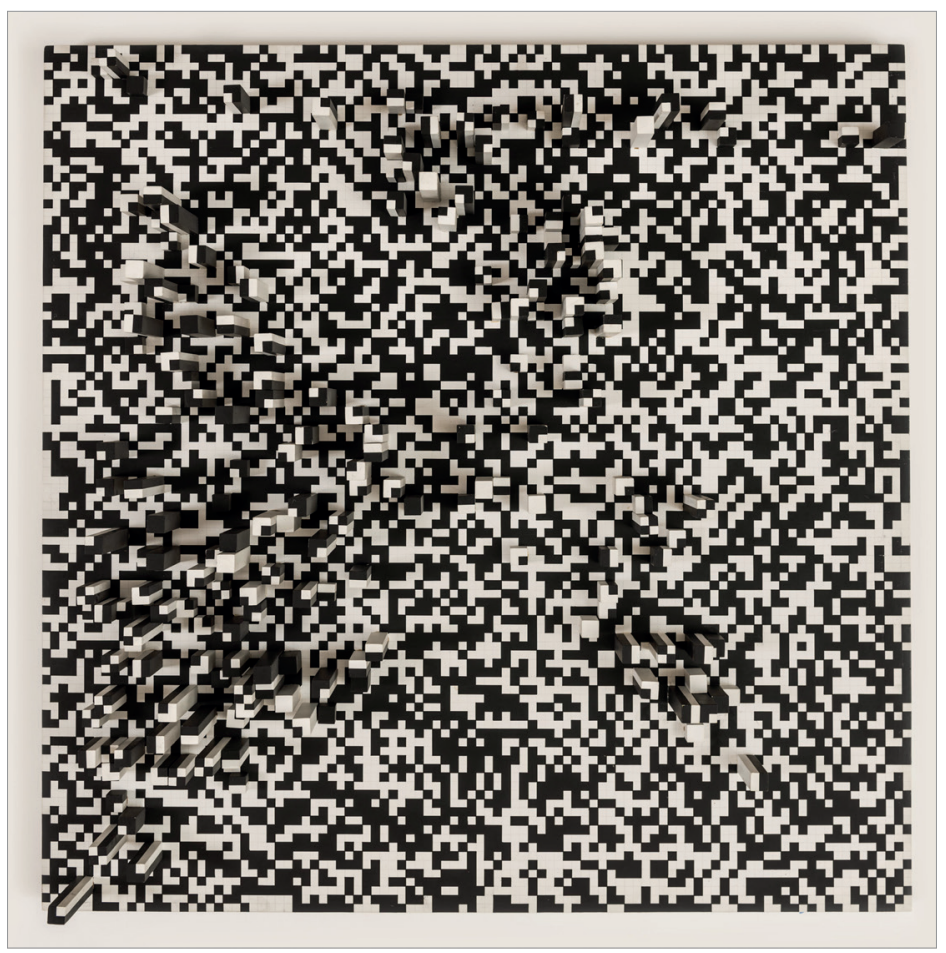

6. Ryszard Winiarski, Obszar 144, akryl na sklejce, drewno, 1973, kolekcja Zachęty - Narodowej Galerii Sztuki

powiadającego Obszarowi 144 ciągu białych i czarnych pól uzyskuje się $2^{10000}$ możliwości. Liczba ta jest o wiele większa od szacowanej całkowitej liczności atomów w obserwowalnym Wszechświecie (wynoszącej blisko $10^{78}$ ), będącej według fizyków największą teoretycznie możliwą do empirycznego doświadczenia przez człowieka wielkością ${ }^{111}$. O ile więc $z$ matematycznego punktu widzenia liczba $2^{10000}$ jest de facto liczbą skończoną, o tyle z punktu widzenia wizualności obrazu lepiej byłoby mówić o nieskończoności potencjalnej lub hilbertowsko rozumianej ponadskończoności, czyli wielkości w matematyce skończonej, lecz w przestrzeni fizycznej wykraczającej poza skończonośćc ${ }^{112}$.

Przestrzenie w obszarach Winiarskiego, zgodnie ze skrótowo zarysowanymi powyżej charakterystykami, są przestrzeniami dyskretnymi, samopodobnymi, dualnymi i ponadskończonymi. Można je nazwać przestrzeniami

111 M. Heller, Początek jest wszędzie. Nowa hipoteza pochodzenia Wszechświata, Warszawa 2002, s. 22.

112 D. Hilbert, O nieskończoności, w: Filozofia matematyki. Antologia tekstów klasycznych, red. i tłum. R. Murawski, Poznań 2003, s. 321-323. 
probabilistycznymi ${ }^{113}$, odnosząc się do kluczowego dla ich interpretacji zagadnienia przypadku. Wspomniane własności są bowiem próbą pojęciowego dookreślenia wizualnie obecnego w dziele „śladu” przypadku, a ich jakościowe połączenie stanowi o unikalnym charakterze prac Winiarskiego.

\section{PODSUMOWANIE}

Zastosowanie metody scjentystycznej, jak starałem się to zaprezentować w powyższych analizach, pozwala wydobyć abstrakcyjne własności przestrzeni w konkretnych dziełach Fangora, Grabowskiego i Winiarskiego, ujawniając kategorie pojęciowe, pozwalające te przestrzenie porównywać - zarówno między sobą, jak i w ramach wielu możliwych do wyodrębniania w twórczości poszczególnych artystów typów przestrzennych. Porównanie wydobywa różnicę i podobieństwo, pozwala uwypuklić nowatorskość poszukiwań artystycznych. W malarstwie abstrakcyinym (i nie tylko abstrakcyinym) nie ma bowiem jednej, „prawdziwej” przestrzeni - jest ich wiele. Ich zróżnicowanie koreluje z implikowanymi ikonicznością obrazu jakościami oglądowymi, a także nierozdzielnym od niej kontekstem interpretacyjnym - naukową wizją rzeczywistości.

Kosmogoniczna przestrzeń obrazów Fangora jest ciągła, otwarta i aktualnie nieskończona, probabilistyczna przestrzeń obszarów Winiarskiego jest zaś nieciągła (dyskretna), wyczerpywalna i potencjalne nieskończona, by wspomnieć jedynie o kilku wyodrębnionych powyżej ich własnościach. Gdzieś „pomiędzy” nimi lokuje się heterogeniczna przestrzeń transcendencji w obrazach i grafikach Grabowskiego, łącząca w sobie ciągłość z dyskretnością, potencjalność i aktualność nieskończoności. Aspekt przestrzeni w twórczości każdego $z$ tych artystów (jak i wielu innych) zasługiwałby na osobne, pełniejsze opracowanie. Mam nadzieję, że zarysowana powyżej mapa zagadnień choć trochę zaświadcza o sile ładunku intelektualno-poznawczego, tkwiącego w omawianym tu przedmiocie badań.

Powyższe analizy wyraźnie akcentują specyfikę sztuki odwołującej się w swej materii wizualno-kontekstowej do nauk ścisłych. Tego typu sztuka jest w pewnym sensie nauką, tyle że uprawianą nie w sposób pojęciowo-symboliczny, lecz obrazowy. Artysta lub artystka, tworzący lub tworząca tego ro-

${ }^{113} \mathrm{~W}$ matematyce funkcjonuje już termin „przestrzeń probabilistyczna” i ma ściśle określone znaczenie (zob. Jakubowski, Sztencel, Rachunek prawdopodobieństwa..., s. 18), które w dużej mierze, z niewieloma modyfikacjami, można przypisać także obrazom Winiarskiego. Pisząc w niniejszym tekście o przestrzeniach probabilistycznych, ograniczam się jednak do charakterystyki przekraczającej ścisłe znaczenie matematyczne. 
dzaju sztukę, nie udowadnia twierdzeń matematycznych, lecz je egzemplifikuje; nie definiuje obiektów matematycznych, lecz uobecnia je w obrazie; analiza nie jest dla niego lub dla niej środkiem prowadzącym do ostatecznego wyniku, lecz odtwarzalnym w oglądzie obrazu procesem myślowym. Sztuka niejako otwiera tutaj oczy matematyce, inicjując tym samym zupełnie inny niż nauka obszar refleksji.

\section{BIBLIOGRAFIA}

Abstraction, red. M. Lind, London-Cambridge 2013

Arnheim R., Sztuka i percepcja wzrokowa. Psychologia twórczego oka, tłum. J. Mach, Łódź 2013

Batóg T., Dwa paradygmaty matematyki. Studium z dziejów i filozofii matematyki, Poznań 2000

Batóg T., Podstawy logiki, Poznań 2003

Bogucki J., Sztuka Polski Ludowej, Warszawa 1983

Bois Y.-A., R.E. Krauss, Formless. A User's Guide, New York 1997

Bondecka-Krzykowska I., Przewodnik po historii matematyki, Poznań 2006

Bondecka-Krzykowska I., Historia obliczeń. Od rachunku na palcach do maszyny analitycznej, Poznań 2012

Breuer H., Atlas fizyki, tłum. J. Gronkowski, Warszawa 2000

Brezine C., Algorithms and Automation. The Production of Mathematics and Textiles, w: The Oxford Handbook of the History of Mathematics, red. E. Robson, J.A. Stedall, Oxford-New York 2009, s. 468-492

Buckley J.J., E. Eslami, An Introduction to Fuzzy Logic and Fuzzy Sets, Heidelberg 2013

Diogenes Laertios, Żywoty i poglądy słynnych filozofów, tłum. I. Krońska, K. Leśniak, W. Olszewski, B. Kupis, Warszawa 2004

Dolphijn R., I. van der Tuin, Nowy materializm. Wywiady i kartografie, tłum. J. Bednarek, J. Maliński, Gdańsk-Poznań-Warszawa 2018

Domańska E., Jakiej metodologii potrzebuje współczesna humanistyka? „Teksty Drugie" 2010, 1/2(121/122), s. 45-55

Domańska E., Historia egzystencjalna. Krytyczne studium narratywizmu i humanistyki zaangażowanej, Warszawa 2012

Duda R., Wprowadzenie do topologii, cz. 1: Topologia ogólna, Warszawa 1986

Dudzik S., Jerzy Grabowski. Artysta i uniwersum, Ząbki 2012

Elsaesser T., M. Hagener, Teoria filmu. Wprowadzenie przez zmysły, tłum. K. Wojnowski, Kraków 2015

Fangor W., ENTER/ESCAPE - Jak malarstwo kształtuje nowe przestrzenie? (Wypowiedzi uczestników wystawy), „Sztuka i Dokumentacja” 2010, 2, s. 75

Fichtenholz G.M., Rachunek różniczkowy i całkowy, t. 1, tłum. T. Huskowski, R. Bittner, B. Gleichgewicht, Warszawa 1999

Garber D., Leibniz. Body, Substance, Monad, Oxford 2009 
Haraway D., Manifest gatunków stowarzyszonych, w: Teorie wywrotowe. Antologia przekładów, red. J. Bednarek, A. Gajewska, tłum. J. Bednarek, Poznań 2012, s. 241-260

Heller M., Początek jest wszędzie. Nowa hipoteza pochodzenia Wszechświata, Warszawa 2002

Heller M., Przestrzenie Wszechświata. Od geometrii do kosmologii, Kraków 2017

Heller M., S. Krajewski, Czy fizyka i matematyka to nauki humanistyczne? Kraków 2014

Henderson L.D., The Fourth Dimension and Non-Euclidean Geometry in Modern Art, Cambridge-London 2013

Hilbert D., Grundlagen der Geometrie, Leipzig 1903

Hilbert D., O nieskończoności, w: Filozofia matematyki. Antologia tekstów klasycznych, red. i tłum. R. Murawski, Poznań 2003, s. 318-340

Hohol M.L., Matematyczność ucieleśniona, w: Oblicza racjonalności. Wokół myśli Michała Hellera, red. B. Brożek, Kraków 2011, s. 143-166

Jakubowski J., R. Sztencel, Rachunek prawdopodobieństwa dla (prawie) każdego, Warszawa 2002

Jänich K., Topologia, tłum. D. Czarnocka-Cieciura, G. Cieciura, Warszawa 1991

Janicka K., Surrealizm, Warszawa 1985

Jerzy Grabowski (1933-2004). Grafika i rysunek, red. M. Nowakowska, tłum. E. Rodzeń-Leśnikowska, Łódź 2008

Kandinski W., O duchowości w sztuce, tłum. S. Fijałkowski, Łódź 1996

Kandinski W., Punkt i linia a płaszczyzna. Przyczynek do analizy elementów malarskich, tłum. S. Fijałkowski, Łódź 2019

Kawa R., J. Lembas, Wstęp do informatyki, Warszawa 2017

Kemp M., The Science of Art. Optical Themes in Western Art from Brunelleschi to Seurat, New Haven-London 1990

Kemp M., Seen/Unseen. Art, Science, and Intuition from Leonardo to the Hubble Telescope, Oxford 2012

Kępińska A., Nowa sztuka. Sztuka polska w latach 1945-1978, Warszawa 1981

King J.P., The Art of Mathematics, New York 1992

Kline M., Mathematics in Western Culture, New York 1953

Knorowski M., Analisis situs, czyli topologia według Fangora, w: Wojciech Fangor. 3 wymiary, Kielce 2005, s. 25-28

Kofler E., Z dziejów matematyki, Warszawa 1962

Kotula A., P. Krakowski, Sztuka abstrakcyjna, Warszawa 1977

Kowalska B., Polska awangarda malarska 1945-1980. Szanse i mity, Warszawa 1988

Kowalska B., Kajetan Sosnowski. Malarz niewidzialnych światów, Warszawa 1998

Kowalska B., Fangor. Malarz przestrzeni, Warszawa 2001

Kowalska B., W poszukiwaniu ładu. Artyści o sztuce, Elbląg-Katowice 2001

Kowalska B., O kilku różnych przestrzeniach Wojciecha Fangora, w: Wojciech Fangor. 3 wymiary, Kielce 2005, s. 3-8

Kowalska B., Sztuka struktur matematycznych, w: Jerzy Grabowski (1933-2004). Grafika i rysunek, red. M. Nowakowska, tłum. E. Rodzeń-Leśnikowska, Łódź 2008, s. 3-7 
Kuratowski K., Wstęp do teorii mnogości i topologii, Warszawa 1977

Ludwiński J., Sztuka w epoce postartystycznej, w: idem, Epoka błękitu, red. J. Hanusek, Kraków 2009

Margolis J., Po dwóch stronach debaty wokół modernizmu/postmodernizmu, w: Czym, w gruncie rzeczy, jest dzieło sztuki? Wykłady z filozofii sztuki, red. K. Wilkoszewska, tłum. W. Chojna, Kraków 2004, s. 12-26

Matematyczność przyrody, red. M. Heller, J. Życiński, A. Michalik, Kraków 1992

Milner J., Kazimir Malevich and the Art of Geometry, New Haven-London 1996

Mioduszewski J., Wykłady z topologii. Topologia przestrzeni euklidesowych, Katowice 1994

Murawski R., Filozofia matematyki. Zarys dziejów, Poznań 2013

Murawski R., Nieskończoność w matematyce. Zmagania z potrzebnym, acz kłopotliwym pojęciem, „Zagadnienia Filozoficzne w Nauce” 2014, 55, s. 5-42

Murawski R., Dlaczego matematyka pozwala rozumieć i opisywać świat? Refleksja filozoficzna, w: idem, Z historii logiki i filozofii matematyki, Poznań 2019, s. 133146

Murawski R., O pojęciu prawdy w matematyce, w: idem, Z historii logiki i filozofii matematyki, Poznań 2019, s. 107-115

Murawski R., K. Świrydowicz, Wstęp do teorii mnogości, Poznań 2005

Olek J., Porządek przypadku, czyli o Winiarskim, w: Ryszard Winiarski. Prace z lat 1973-1974, red. J. Grabski, Kraków 2002

Omnès R., Converging Realities. Toward a Common Philosophy of Physics and Mathematics, Princeton 2005

Ornes S., Math Art. Truth, Beauty, and Equations, New York 2019

O'Sullivan S., From Aesthetics to the Abstract Machine: Deleuze, Guattari and Contemporary Art Practice, w: Deleuze and Contemporary Art, red. S. Zepke, S. O'Sullivan, Edinburgh 2010, s. 189-207

Palka Z., A. Ruciński, Wykłady z kombinatoryki. Przeliczanie, Warszawa 2007

Panofsky E., Perspektywa jako „forma symboliczna”, tłum. G. Jurkowlaniec, Warszawa 2008

Peitgen H.-O., H. Jürgens, D. Saupe, Fraktale. Granice chaosu, cz. 1, tłum. K. Pietruska-Pałuba, K. Winkowska-Nowak, Warszawa 2002

Peitgen H.-O., H. Jürgens, D. Saupe, Fraktale. Granice chaosu, cz. 2, tłum. K. Pietruska-Pałuba, K. Winkowska-Nowak, Warszawa 1995

Perspektywa sztuki matematycznej, red. W. Skrodzki, „Współczesność. Czasopismo Literackie" 1967, 14(241), s. 8-11

Piegat A., Modelowanie i sterowanie rozmyte, Warszawa 1999

Porębski M., Kubizm. Wprowadzenie do sztuki XX wieku, Warszawa 1986

Porfiriusz, Żywot Pitagorasa, w: Żywoty Pitagorasa, red. i tłum. J. Gajda-Krynicka, Wrocław 1993, s. 1-24

Reale G., Historia filozofii starożytnej, t. 2: Platon i Arystoteles, tłum. E. Łupina, E.I. Zieliński, M. Podbielski, Lublin 2008

Reinhardt F., H. Soeder, Atlas matematyki, tłum. Ł. Wiechecki, Warszawa 2006

Rosenfeld B.A., History of Non-Euclidean Geometry. Evolution of the Concept of a Geometric Space, New York 1988 
Roskal Z.E., Koncepcje przestrzeni w nauce i filozofii przyrody, „Roczniki Filozoficzne" 2008, 1(56), s. 279-294

Rota G.-C., The Pernicious Influence of Mathematics upon Philosophy, "Synthese” $1991,2(88)$, s. $165-178$

Rottenberg A., Sztuka w Polsce 1945-2005, Warszawa 2005

Rozmowa z Wojciechem Fangorem. Kwiecień-Maj 2003, w: Wojciech Fangor (Centrum Sztuki Współczesnej Zamek Ujazdowski Warszawa, 16 września - 26 października 2003), Warszawa 2003, s. 54-72

Rybka E., Astronomia ogólna, Warszawa 1975

Ryszard Winiarski. Event-Information-Image, red. A. Muszyńska, M. Marczak-Cerońska, Warszawa 2017

Schröder B., Konkrete Kunst. Mathematisches Kalkül und programmiertes Chaos, Berlin 2008

Seel M., Estetyka obecności fenomenalnej, red. K. Wilkoszewska, tłum. K. Krzemieniowa, Kraków 2008

Shlain L., Art \& Physics. Parallel Visions in Space, Time, and Light, New York 2007

Skarbek J., Scjentyzm, w: Z. Musiał, J. Skarbek, B. Wolniewicz, Trzy nurty: racjonalizm - antyracjonalizm - scjentyzm, Warszawa 2006, s. 167-223

Sokal A.D., J. Bricmont, Modne bzdury. O nadużywaniu pojęć z zakresu nauk ścisłych przez postmodernistycznych intelektualistów, tłum. A. Lewańska, P. Amsterdamski, Warszawa 2004

Steiner M., The Applicability of Mathematics as a Philosophical Problem, Cambridge-London 1998

Strosberg E., Art \& Science, New York-London 2015

Sztabińska P., Geometria a natura. Polska sztuka abstrakcyjna w drugiej połowie XX wieku, Warszawa 2010

Szydłowski S., Przestrzeń znaczy wolność. O twórczości Wojciecha Fangora, w: Wojciech Fangor. 3 wymiary, Kielce 2005, s. 19-23

Szydłowski S., Wojciech Fangor. Przestrzeń jako gra, Kraków 2012

Szydłowski S., Woiciech Fangor. 3 wymiary - retrospektywa, Orońsko 2015

Szydłowski S., Wprowadzenie, w: Wojciech Fangor. Heweliusz, red. I. Ziętkiewicz, tłum. B. Łuniewicz, Sopot 2015, s. 7-18

Świrydowicz K., Podstawy logiki modalnej, Poznań 2014

Taranienko Z., Dialogi o sztuce, Warszawa 2004

Theories and Documents of Contemporary Art. A Sourcebook of Artists' Writings, red. K. Stiles, P.H. Selz, Berkeley 1996

Toepell M.-M., Über die Entstehung von David Hilberts „Grundlagen der Geometrie", Göttingen 1986

Torretti R., Philosophy of Geometry from Riemann to Poincaré, Dordrecht 1978

Virilio P., Maszyna widzenia, w: Widzieć, myśleć, być: technologie mediów, red. A. Gwóźdź, Kraków 2001, s. 39-62

Wiesing L., Widzialność obrazu. Historia i perspektywy estetyki formalnej, tłum. K. Krzemień-Ojak, Warszawa 2008 
Wigner E.P., Niepojęta skuteczność matematyki w naukach przyrodniczych, w: Współczesna filozofia matematyki. Wybór tekstów, red. R. Murawski, Warszawa 2002, s. 293-309

Wilder R.L., Kulturowa baza matematyki, w: Współczesna filozofia matematyki. Wybór tekstów, red. R. Murawski, Warszawa 2002, s. 275-292

Winiarski R., Moje próby i poszukiwania, „Polska” 1966, 11(147), s. 42-43

Wojciech Fangor: 25.09.2009-15.11.2009, red. S. Szydłowski, Warszawa 2009

Wojciechowski A., Młode malarstwo polskie 1944-1974, Wrocław 1983

Wójtowicz K., Spór o istnienie w matematyce, Warszawa 2003

Wszołek S., Matematyka i metafizyka. Krótki komentarz na temat hipotezy matematyczności świata, „Studia Philosophiae Christianae” 2010, 1(46), s. 25-36

Wywiad z Ryszardem Winiarskim, rozm. D. Skaryszewska, „Projekt” 1985, 5(164), s. $22-27$

Eukasz Rozmarynowski

Adam Mickiewicz University, Poznań

MULTIFARIOUS SPACE OF ABSTRACTION.

A CATEGORY OF SPATIALITY IN THE WORKS OF WOJCIECH FANGOR, JERZY GRABOWSKI AND RYSZARD WINIARSKI A COMPARATIVE STUDY

\section{Summary}

If one were to indicate some tendencies characteristic of the art of the $20^{\text {th }}$ century, the pursuit of making artwork more spatial would certainly be one of them. This tendency manifests itself in the myriad of symptoms: an avant-garde redefinition of sculpture with its negative space; a proliferation of kinetic works enabling spectators to (re) shape artwork's matter more actively; a dissemination of ephemeral forms, especially happening and performance; beginnings of installation art, to mention but a few. The present paper sets out to examine an artistic phenomenon which is not as spectacular as the aforementioned examples, but it could be somehow placed at the intersection of them. One can consider the particular type of abstract painting, embedded in a pictorial plane and slightly opening for surrounding space, but simultaneously reconceptualising the relation between the imagined and the physically present.

The first part of the article deals with methodology. As far as research is concerned, the author assumes moderate scientism as the methodological perspective. It is based on the belief that mathematical sciences throughout history have developed notions and analytical methods allowing the observable and communicable features of things, including artworks and artistic phenomena, to be explained in an effective way, i.e. more faithfully and usefully. Because of the fact that mathematical truths are not absolute, the methodological perspective is called 'moderate'. Taking into account these 
assumptions, the second part of the article defines the analytical category of spatiality, which expresses painting's ability to evoke variously conceptualised spaces.

The three subsequent sections of the article are devoted to some paintings by three Polish artists active in the second half of the $20^{\text {th }}$ century, i.e. Wojciech Fangor, Jerzy Grabowski, Ryszard Winiarski. Each of them combined two differently understood spatial orders in their works: physical (related to phenomenological and sensual experience) and conceptual (related to notions and theories proposed by exact sciences). Having analysed a number of paintings by Fangor, Grabowski and Winiarski, one can define notions of cosmogonic, transcendence and probabilistic space, respectively. In summary, the specificity of works analysed in the context of ideas drawn from exact sciences is examined.

Keywords:

spatiality; moderate methodological scientism; Wojciech Fangor; Jerzy Grabowski; Ryszard Winiarski 